\title{
Cytotoxic Effects of Sigma Ligands: Sigma Receptor-mediated Alterations in Cellular Morphology and Viability
}

\author{
Bertold J. Vilner, Brian R. de Costa, and Wayne D. Bowen \\ Unit on Receptor Biochemistry and Pharmacology, Laboratory of Medicinal Chemistry, National Institute of Diabetes and \\ Digestive and Kidncy Discases, Bethesda, Maryland 20892
}

The morphological effects of several neuroleptics as well as other novel and prototypic sigma ligands were examined by addition to cultures of $\mathbf{C 6}$ glioma cells. Sigma ligands caused loss of processes, assumption of spherical shape, and cessation of cell division. The time course and magnitude of this effect were dependent on the concentration of sigma ligand. Continued exposure to sigma compounds ultimately resulted in cell death. However, the morphological effect was reversible when sigma ligand was removed shortly after rounding. The potency of compounds to produce these effects generally correlated with binding affinity at sigma receptors of $\mathrm{C} 6$ glioma cell membranes labeled with $\left[{ }^{3} \mathrm{H}\right](+)-$ pentazocine. At a concentration of $100 \mu \mathrm{m}$, haloperidol, reduced haloperidol, fluphenazine, perphenazine, trifluoperazine, BD737, LR172, BD1008, and SH344 produced significant effects in 3-6 hr of exposure. Other compounds, such as trifluperidol, thioridazine, and (-)-butaclamol, produced significant effects by $24 \mathrm{hr}$ of exposure. Despite the requirement of micromolar concentrations of ligand (some compounds were effective at $30 \mu \mathrm{M}$ ), the effect showed a remarkable specificity for compounds exhibiting sigma receptor binding affinity. Neuroleptics lacking potent sigma affinity [e.g., (-)-sulpiride, (+)-butaclamol, and clozapine] and other compounds that lack significant sigma affinity but that are agonists or antagonists at dopamine, serotonin, adrenergic, glutamate, phencyclidine, GABA, opiate, or muscarinic cholinergic receptors were without effect on cellular morphology at concentrations up to $300 \mu \mathrm{m}$ over a period of $72 \mathrm{hr}$. Likewise, blockers and activators of $\mathrm{Na}^{+}, \mathrm{K}^{+}$, and $\mathrm{Ca}^{2+}$ channels and a monoamine oxidase inhibitor devold of sigma affinity were without effect. Interestingly, 1,3-di-o-tolylguanidine (DTG), (+)-3-(3-hydroxyphenyl)-N-(1-propyl)piperidine [(+)-3-PPP], (+)-pentazocine, (+)-cyclazocine, and other sigma-active benzomorphans and morphinans appeared inactive in up to $72 \mathrm{hr}$ of culture. However, these compounds interacted synergistically with a subeffective dose of BD737 $(30 \mu \mathrm{M})$ to produce effects usually in $6 \mathrm{hr}$ or less. Also, the $\mathrm{pH}$ of the culture medium had a profound

\footnotetext{
Received Dec. 31, 1993; revised Apr. 20, 1994; accepted June 9, 1994.

We acknowledge Dr. F. I. Carroll, Research Triangle Institute, and Dr. Kenner C. Rice, NIDDK, for providing some of the opiate-related compounds used in this study. We also acknowledge Dr. Xiao-shu He, NIDDK, for the synthesis of SH322, SH344, and SH384.

Correspondence should be addressed to Wayne D. Bowen, Ph.D., Chief, Unit on Receptor Biochemistry and Pharmacology, Laboratory of Medicinal Chemistry, NIDDK, Building 8, Room B1-23, 9000 Rockville Pike, Bethesda, MD 20892.

Copyright $(\mathcal{C} 1995$ Society for Neuroscience $0270-6474 / 95 / 150117-18 \$ 05.00 / 0$
}

effect on the activity of sigma compounds. Increasing the $\mathrm{pH}$ from the normal range of 7.2-7.4 to $\mathrm{pH}$ 8.3-8.5 shifted the dose curves $(30,100,300 \mu \mathrm{M})$ for all sigma compounds to the left. Under these conditions, DTG, (+)-3-PPP, and benzomorphans produced effects in $24 \mathrm{hr}$ or less. Decreasing the medium $\mathrm{pH}$ to 6.5-6.7 markedly reduced the activity of all sigma ligands, producing significant protectlon from cytotoxic effects. Importantly, compounds that lacked sigma binding affinity showed neither synergism with $30 \mu \mathrm{M}$ BD737 nor an increase in activity at higher $\mathrm{pH}$. These results confirm the sigma receptor specificity of this effect. Sigma ligands had similar effects on other cells of neuronal and non-neuronal origin, including SK-N-SH and SH-SY5Y neuroblastomas, NCB-20 hybridoma, NG 108-15 neuroblastoma-glioma hybrid, COS-7 (kidney), MRS-5 (lung), and PC12 pheochromocytoma. These results suggest that sigma receptors play some vital role in cell function and may have important implications for neurodegenerative disorders and neuroleptic treatment.

[Key words: sigma receptors, neuroleptics, cytotoxicity, neurodegeneration, 66 glioma, haloperidol]

Sigma receptors are saturable, high-affinity binding sites for several important classes of psychotropic drugs, and have received intensive study in recent years (Musacchio et al., 1989a; Itzhak and Stein, 1990; Walker et al., 1990, 1993b; Ferris et al., 1991; Su, 1991; Bowen, 1993; Debonnel, 1993). These receptors are distinct in pharmacological profile, tissue distribution, and subcellular localization from any known neurotransmitter or hormone receptor. Sigma sites are located not only in the CNS, but also occur in high density in several peripheral tissues, including liver and endocrine tissue such as testis and ovary. At least two classes of sigma sites, termed sigma-1 and sigma-2, have been identified (Walker et al., 1990; Quirion et al., 1992). These sites are distinguishable by their affinity for dextrorotatory benzomorphans and by molecular size (Hellewell and Bowen, 1990; Di Paolo et al., 1991; Bowen et al., 1993; Hellewell et al., 1994. Though the exact role of sigma receptors in synaptic transmission and cell function is still largely unknown, sigma sites have been implicated in a number of biochemical, physiological, and behavioral processes including motor control, neurotransmitter synthesis and release, ileal smooth muscle contraction, duodenal bicarbonate secretion, and modulation of muscarinic and $\mathrm{N}$-methyl-D-aspartate (NMDA) receptor function (Walker et al., 1990, 1993b; Bowen, 1993; Debonnel, 1993).

Much of the initial interest in sigma sites has stemmed from their high affinity for most of the typical antipsychotic drugs. 
Among these are haloperidol, fluphenazine, and perphenazine. In view of this, sigma sites have been implicated in the etiology of psychosis and have been viewed as an alternative target to dopamine $\mathrm{D}_{2}$ receptors for antipsychotic drug design. Because sigma receptors occur in very high density in motor regions of the brain, such as brainstem motor nuclei, substantia nigra, and cerebellum, sigma sites have also been proposed to contribute to the untoward motor side effects resulting from acute and chronic neuroleptic treatment (Walker et al., 1988). Consistent with this, microinjection of haloperidol, 1,3-di-o-tolylguanidine (DTG), (+)-pentazocine, and other sigma ligands into the rat red nucleus causes acute dystonic reactions, reminiscent of the acute reactions observed in patients receiving neuroleptic treatment (Walker et al., 1988; Matsumoto et al., 1990). In the course of investigating the behavioral effects of haloperidol and its metabolites by microinjection into the red nucleus of the rat, we discovered that reduced haloperidol, a major metabolite and potent sigma ligand, was neurotoxic (Bowen et al., 1990). The compound caused extensive gliosis and loss of magnocellular neurons in and around the area of microinjection. These pathologic changes were accompanied by long-lasting ( $>3 \mathrm{~d}$ ) postural abnormalities. Similar results were observed with BD614, a novel and highly selective sigma ligand (Bowen et al., 1992). It was difficult, initially, to link these effects with action at sigma receptors since other sigma ligands tested had produced only short-lived $(90 \mathrm{~min})$ postural effects with no signs of histological damage.

We have recently shown that sigma-1 and sigma- 2 sites are present in several clonal cell lines, including NB41A3, N1E115 , and S20-Y neuroblastomas, C6 glioma, and the NG10815 neuroblastoma-glioma hybrid cell line (Vilner and Bowen, 1992; Vilner et al., 1992). This suggested that these cells could serve as appropriate model systems in which to study sigma receptor function. To investigate the possible role of sigma receptors in the neurotoxic effect described above, we investigated the effect of a limited series of neuroleptics on C6 glioma cells in culture (Vilner and Bowen, 1993). Neuroleptics that exhibited sigma binding affinity such as haloperidol and fluphenazine caused marked morphological changes and, ultimately, cell death. Rank order of potency correlated generally with sigma binding affinity. Neuroleptics lacking sigma affinity and ligands for other receptors failed to produce this effect. We have synthesized and characterized an extensive series of novel compounds based on $N$-[arylethyl]- $N$-alkyl-2-(1-pyrrolidinyl)ethylamine for binding affinity and selectivity at sigma sites (Radesca et al., 1991; Bowen et al., 1992; de Costa et al., 1992a,b, 1993; He et al., 1993). Here, we extend our studies on C6 glioma cells to compounds of the aryl ethyl(pyrrolidinyl)cyclohexylamine, aryl ethylene diamine, and aryl alkyl piperazine series (see Materials and Methods), and also investigate the actions of several additional neuroleptics, prototypic sigma ligands, and non-sigma compounds. Effects of compounds were then compared with binding affinities at $\mathrm{C} 6$ glioma sigma-1-like sites labeled by $\left[{ }^{3} \mathrm{H}\right](+)$-pentazocine (Bowen et al., 1993). The effects of sigma ligands on other cell lines of various origins were also investigated.

\section{Materials and Methods}

Effect of compounds on cultured cells Cell culture

Rat C6 glioma cells (American Type Culture Collection, Rockville, MD) were cultured in Dulbecco's Modified Eagle's Medium (DMEM) (Life Technologies, Inc.-GIBCO BRL, Grand Island, NY) supplemented with
$44 \mathrm{~mm}$ sodium bicarbonate and $10 \%$ fetal bovine serum (FBS) (Advanced Biotechnologies, Inc., Columbia, MD) in 24-well plastic plates (Costar, Cambridge, MA) in a humidified atmosphere of $5 \% \mathrm{CO}_{2} / 95 \%$ air (normal conditions, pH 7.2-7.4). For all drug additions, FBS was reduced from $10 \%$ to $1 \%$. Where specified, the $\mathrm{pH}$ of culture medium was altered from normal during treatment of cells with drugs. For alkaline conditions ( $\mathrm{pH} 8.3-8.5$ ), cells were cultured in the above medium in humidified air only. This was accomplished by placing plates inside of a sealed desiccator that contained normal room air and water (for humidity), and maintaining the desiccator at $37^{\circ} \mathrm{C}$ inside of an incubator. For acidic conditions (pH 6.5-6.7) cells were cultured in humidified $5 \%$ $\mathrm{CO}_{2} / 95 \%$ air in either Dulbecco's phosphate-buffered saline (Life Technologies, Inc.-GIBCO BRL, Grand Island, NY) supplemented with 1$2 \%$ FBS or L-15 medium (GIBCO-Bethesda Research Labs, Grand Island, NY) supplemented with $1 \%$ FBS, both without sodium bicarbonate. Cells were preplated $1-2 \mathrm{~d}$ before the start of the experiment, at a density of 5-6 $\times 10^{3}$ or $1 \times 10^{4}$ cells $/ \mathrm{cm}^{2}$ to avoid contact inhibition of dividing cells during the $3 \mathrm{~d}$ observation period.

SK-N-SH human neuroblastoma (ATCC, Rockville, MD), SH-SY5Y subclone of SK-N-SH (from Dr. Tommaso Costa, NICHD/NIH, Bethesda, MD), NCB-20 mouse neuroblastoma $\times$ Chinese hamster brain hybrid (from Dr. Richard Miller, University of Chicago, Chicago, IL), NG108-15 mouse neuroblastoma $\times$ rat glioma hybrid (from Dr. Richard Weber, NIDDK, Bethesda, MD), COS-7 African green monkey SVtransformed kidney (ATCC, Rockville, MD), and MRS-5 human lung, diploid, x-irradiated (ATCC, Rockville, MD), were cultured as described above for $\mathrm{C} 6$ glioma cells. PC12 pheochromocytoma were cultured in RPMI 1640 (Sigma Chemical Co., St. Louis, MO) supplemented with $23 \mathrm{~mm}$ sodium bicarbonate, $10 \%$ horse serum (Advanced Biotechnologies, Inc.), and 5\% fetal bovine serum (Advanced Biotechnologies, Inc.). PC12 cells were differentiated before use by treatment for $14 \mathrm{~d}$ with 50-100 biological units of nerve growth factor (NGF) (Advanced Technologies, Inc.). In all cases, serum was reduced to $1 \%$ during treatment with drugs.

\section{Scoring of morphological effects}

After exchange of culture medium for medium containing the test compound (usually $100 \mu \mathrm{M}$ unless specified otherwise), the cells were monitored at various times up to $72 \mathrm{hr}$ by phase-contrast microscopy at $10 \times$ or $20 \times$. The effect of each compound was scored relative to a control receiving only solvent vehicle. Cells were observed every $2 \mathrm{hr}$ during the first $6 \mathrm{hr}$ and then once every $24 \mathrm{hr}$ after drug addition. Scoring was done with respect to both time after addition of test compound (usually 6,24 , and $72 \mathrm{hr}$ ) and extent of cellular changes (N, A, B, C, or D) as follows (see Fig. 1 and text for detailed descriptions): N, no observable effect on cells; A, significant proportion of cells exhibit loss of fine processes; $\mathrm{B}$, all cells have lost fine processes and some cells remain polygonal with coarse processes, while others become spindle shaped or round; $C$, most or all cells have become round; D, cell death with presence of cell debris. In some cases, cell viability was determined by trypan blue exclusion to confirm visual inspection.

Although the first observer was not drug blind, each sample was independently scored by a second observer who was blind to the drug condition. Experiments were repeated at least twice, with most being repeated three times. When both observers gave the same score in each of the repeated experiments, the score was given as a single letter. Three types of situations resulted in assignment of a score range (e.g., "A-B"). A score range was given (1) when the cells appeared to be midway between two stages shown in Figure 1, (2) if there was disagreement between the two observers in any of the repeated experiments, or (3) if the observers agreed on the score in each of the repeated experiments but the results between experiments called for different scores. Scoring agreement between the two observers and reproducibility of scores between experiments was quite good, as indicated by the number of singleletter scores shown in the tables.

\section{Radioligand binding}

Membrane preparation. C6 glioma cells were cultured as described above with $10 \%$ FBS, except cells were plated at a density of $2 \times 10^{6}$ cells $/ 75$ $\mathrm{cm}^{2}$ or $150 \mathrm{~cm}^{2}$ plastic flask (Corning Co., Corning, NY) and medium was changed 1-2 times a week. Cells were allowed to grow to near confluency (overgrowth not exceeding three-fourths or four-fifths of entire square surface of flasks). After decantation of the medium, the cells were washed in situ with Hank's balanced salt solution (HBSS). 

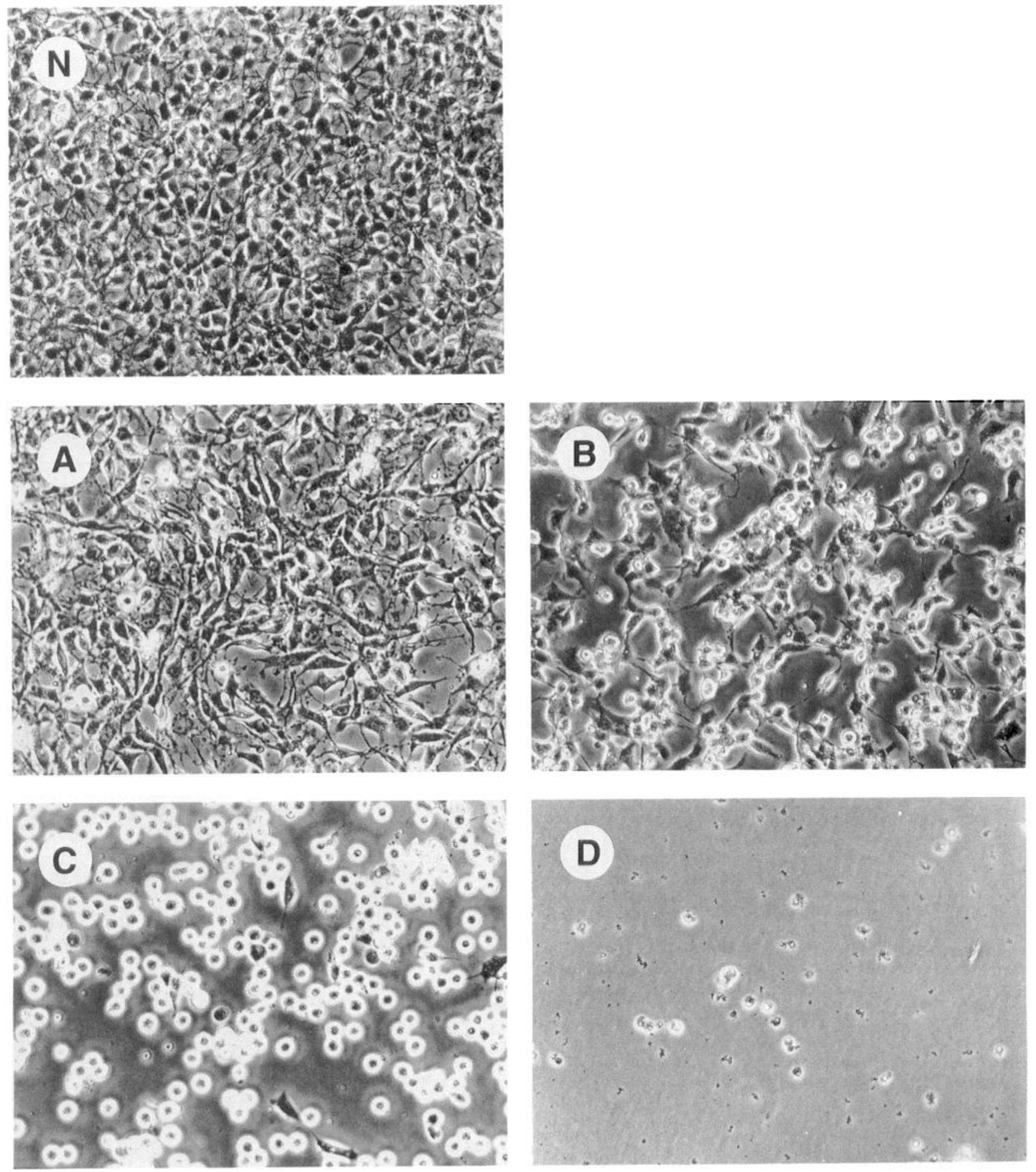

Figure 1. Morphological changes in C6 glioma cells produced by sigma ligands. C6 glioma cells were plated and cultured as described in Materials and Methods in the absence or presence of a test compound. Cells were monitored at various times up to $72 \mathrm{hr}$ by phase-contrast microscopy at $10 \times$ or $20 \times$. The panels represent various stages of the effect of test compound as described in detail in the text. The scores assigned ( $N, A, B$, $C$, and $D$ ) correspond to the letter of the panel. $N$, Normal cells as they appear before addition of any test compound. Cells were given a score of "N" when there was no effect relative to an untreated control. $A$. Significant proportion of cells exhibit loss of fine processes. $B$, All cells have lost fine processes and some cells have become polygonal, spindle-shaped, or round. $C$, Most or all cells have become round. $D$, Cell death with presence of cell debris. Photographs are from representative experiments. 
The cells were then detached by scraping with a cell scraper (Costar Corporation, MA) in HBSS. Suspended cells were centrifuged for 5-7 min at $1,000 \mathrm{rpm}$ in a cold table-top centrifuge. The cell pellet was resuspended in ice-cold $10 \mathrm{~mm}$ Tris-IICl, pII 7.4, containing $0.32 \mathrm{M}$ sucrose to a concentration of $1 \times 10^{7}-10^{8} \mathrm{cells} / \mathrm{ml}$ and homogenized by $10-12$ hand-driven strokes in a Potter-Elvehjem homogenizer (Teflon pestle). The degree of homogenization was checked using the trypan blue exclusion test. In some cases, the homogenate was then centrifuged at $31,000 \times g$ for $15 \mathrm{~min}$ at $4^{\circ} \mathrm{C}$ and the supernatant discarded ("crude" preparation). In other cases the homogenate was centrifuged at 1,000 $\times g$ prior to the $31,000 \times g$ spin $\left(\mathrm{P}_{2}\right.$ preparation). In either case, the final pellet was resuspended in ice-cold $10 \mathrm{~mm}$ Tris- $\mathrm{HCl}, \mathrm{pH} \mathrm{7.4,} \mathrm{to} \mathrm{a}$ protein concentration of $15-20 \mathrm{mg} / \mathrm{ml}$, and aliquots stored at $-80^{\circ} \mathrm{C}$ until use. Protein concentration was determined by the method of Lowry et al. (1951) using bovine serum albumin as standard. Similar results were obtained with "crude" and $\mathrm{P}_{2}$ membranes.

Sigma receptor binding. Sigma receptors (sigma-1 sites) were labeled using $\left[{ }^{3} \mathrm{H}\right](+)$-pentazocine $(51.7 \mathrm{Ci} / \mathrm{mmol}$ ) (deCosta ct al., 1989; Bowen et al., 1993). Binding was carried out in a final volume of $0.25 \mathrm{ml}$ of $50 \mathrm{~mm}$ Tris- $\mathrm{HCl}, \mathrm{pH} 8.0$, for $120 \mathrm{~min}$ at $37^{\circ} \mathrm{C}$ using $30 \mathrm{~nm}$ radioligand and $100-200 \mu \mathrm{g}$ of membrane protein. Nonspecific binding was determined in the presence of $10 \mu \mathrm{M}(+)$-pentazocine. A similar level of nonspecific binding was observed using $10 \mu \mathrm{M}$ haloperidol. Assays were terminated by addition of $5 \mathrm{ml}$ of ice-cold $10 \mathrm{~mm}$ Tris- $\mathrm{HCl}, \mathrm{pH} 7.4$, and filtration through glass fiber filters using a Brandel cell harvester (Brandel, Gaithersburg, MD). Filters were then washed twice with $5 \mathrm{ml}$ of ice-cold buffer. Filters were soaked in $0.5 \%$ polyethyleneimine for at least $30 \mathrm{~min}$ at $25^{\circ} \mathrm{C}$ prior to use. The filters were counted in Ecoscint (National Diagnostics, Manville, NJ) or CytoScint (ICN, Costa Mesa, CA) after an overnight extraction of counts.

\section{Chemicals}

$\left[{ }^{3} \mathrm{H}\right](+)$-Pentazocine $(51.7 \mathrm{Ci} / \mathrm{mmol})$ was synthesized as described previously (de Costa et al., 1989). Tris- $\mathrm{HCl}$, polyethyleneimine, haloperidol, perphenazine, and tissue culture reagents (RPMI 1640, L15, Hank's BSS, trypan blue) were purchased from Sigma Chemicals (St. Louis, MO). DMEM and Dulbecco's PBS were purchased from Life Technologies, Inc.-GIBCO BRL (Grand Island, NY). Fetal bovine serum, horse serum, and nerve growth factor were purchased from Advanced Biotechnologies, Inc. (Columbia, MD). Novel sigma ligands based on the aryl ethylene diamine pharmacophore were synthesized as described previously (Radesca et al., 1991; de Costa et al., 1992a,b, 1993; He et al., 1993). Morphine, naltrexone, and levallorphan were obtained from NIDA. Dextrallorphan, dextromethorphan, $(+)$-naltrexone, $(+)$-etorphine, and enantiomers of pentazocine and $N$-allyl-normetazocine (SKF 10,047) were provided by Dr. Kenner C. Rice (NIDDK, Bethesda, MD). Enantiomers of cyclazocine, normetazocine, $N$-benzylnormetazocine, and deoxy-pentazocine were provided by Dr. F. I. Carroll (Research Triangle Institute, Research Triangle Park, NC) and synthesized as previously described (Carroll et al., 1992a,b). DTG was purchased from Aldrich Chemical Co. (Milwaukee, WI). Neuroleptics, reduced haloperidol, haloperidol metabolite I (piperidine metabolite), haloperidol metabolitc III (carboxylic acid metabolitc), ( 1 )-3-(3-hydroxyphenyl)$N$-(1-propyl)piperidine [(+)-3-PPP], and various other receptor agonists, antagonists, ion channel modulators, and enzyme inhibitors were purchased from Research Biochemicals Inc. (Natick, MA).

The following list defines the chemical code names used in the text: BD614, ( \pm )-cis- $N$-[2-(3,4-dichlorophenyl)ethyl]- $N$-methyl-2-(1-pyrrolidinyl)-cyclohexylamine; BD737, $1 S, 2 R$-cis- $N$-[2-(3,4-dichlorophenyl)ethyl]- $N$-methyl-2-(1-pyrrolidinyl)-cyclohexylamine; BD1006, $N$-methyl-2-(1-pyrrolidinyl)ethylamine; BD 1008, $N$-[2-(3,4-dichlorophenyl)ethyl]- $N$-methyl-2-(1-pyrrolidinyl)ethylamine; BD1018, 3S-1-[2(3,4-dichlorophenyl)ethyl]-1,4-diazabicyclo[4.3.0]nonane; BD1047, $N$ [2-(3,4-dichlorophenyl)ethyl]- $N, N^{\prime}, N^{\prime}$-trimethylethylenediamine; BD1063, 1-[2-(3,4-dichlorophenyl)ethyl]-4-methylpiperazine; BD1073, 1-[2-(3,4-dichlorophenyl)ethyl]-4-(n-propyl)piperazine; BD1101, 1-[2(3,4-dichlorophenyl)ethyl]-4-ethylpiperazine; BDI 139, $N$-[2-(3,4-dichlorophenyl)ethyl]- $N, N^{\prime}$-dimethylethylenediamine; BD1216, 4-[2-(3,4dichlorophenyl)ethyl]-1,4-diazabicyclo[3.2.2]nonane; JLII-147, 2-[ $N$-[2-[1-pyrrolidinyl]ethyl]- $N$-methylamino]-6,7-dichlorotetralin; LR 172, $N$-[2-(3,4-dichlorophenyl)ethyl]- $N$-methyl-2-(1-homopiperidinyl)ethylamine; SH322, 1-[2-(3,4-dichlorophenyl)ethyl]-4-( $n$-butyl)piperazine; SH344, $N$-[2-(4-iodophenyl)ethyl]- $N$-methyl-2-(1-pyrrolidinyl)ethylamine; $\mathrm{SH} 384, N$-[2-(3-iodophenyl)ethyl]- $N$-methyl-2-(1- pyrrolidinyl)ethylamine; and (+)-MK-801, (+)-10,11-dihydro-5-methyl-5H-dibenzo[a,d]cyclohepten-5,10-imine.

\section{Results}

General description of morphological effects

Sigma ligands were found to produce dramatic changes in the morphology of C6 glioma cells. Figure 1 shows representative photographs of the progression of morphological changes produced by sigma ligands and the letter code assigned to them for the purpose of this study. Cultures of normal cells $(\mathrm{N})$ without drug addition consisted of flattened polygonal cells with a more or less prominent nucleus and one or two nucleoli. These cells developed an intermingled network of multipolar and branched glial processes. Because the cells were not synchronized, cells at various stages of development were present during these experiments. Thus, a small percentage of round and dividing cells could be seen among the flattened attached cells. Cells were given a score of " $N$ " (Fig. $1 N$ ) when the drug or manipulation produced no significant effect relative to untreated controls. As shown by a score of "A" (Fig. $1 A$ ), the earliest visible effect of test compound was a loss of fine processes. This was accompanied by a partial loss of continuity of the monolayer formed by the network of cells and overlapping processes. A score of "B" (Fig. $1 B$ ) represents the further loss of processes. Fmpty spaces devoid of processes became apparent, as did the presence of polygonal cells with coarse processes and spindle-shaped or round cells. The next stage is represented by " $\mathrm{C}$ " (Fig. 1C), where no cells have processes and the vast majority of cells are round. These cells were viable and most excluded trypan blue. Stage "D" (Fig. 1D) represents cells that are dead or cells that appear to be losing the integrity of their membranes. A large amount of cell debris is present and any cells present at this stage failed to exclude trypan blue. The effects of sigma compounds were qualitatively the same.

\section{Effect of neuroleptics}

Table 1 shows that several neuroleptic compounds $(100 \mu \mathbf{M})$ from at least five different structural classes that arc active at sigma receptors produced changes in cell morphology. Given the qualitative nature of the assay, the potency of compounds to produce these effects roughly correlated with rank order of binding affinity at sigma receptors labeled by $\left[{ }^{3} \mathrm{H}\right](+)$-pentazocine in $\mathrm{C} 6$ glioma cell membranes. The neuroleptics haloperidol, fluphenazine, perphenazine, and trifluoperazine produced significant effects in 3-6 hr of exposure. Other neuroleptics, such as trifluperidol, thioridazine, pimozide, and spiperone, produced significant effects by $24 \mathrm{hr}$ of exposure, as did the putative atypical neuroleptic rimcazole. Morphological effects of neuroleptics were both dose and time dependent (see Table 6 below). Concentrations of drug lower than $100 \mu \mathrm{M}$ were also effective, with morphological changes taking longer to develop. (-)-Sulpiride and clozapine, which lack sigma affinity, were inactive. Also, (-)-butaclamol exhibited activity while $(+)$-butaclamol did not, again consistent with affinity at sigma sites labeled by $\left[{ }^{3} \mathrm{H}\right](+)$-pentazocine.

Three metabolites of haloperidol have previously been evaluated for sigma binding affinity in rat brain membranes (Bowen et al., 1990). These metabolites were examined here for ability to produce morphological changes and sigma affinity in C6 glioma cells. The two sigma receptor-active metabolites, reduced haloperidol and piperidine metabolite, produced morphological changes, while the sigma receptor-inactive carboxylic acid me- 
Table 1. Effect of neuroleptics on C6 glioma cells

\begin{tabular}{|c|c|c|c|c|c|}
\hline \multirow[b]{2}{*}{ Compound } & \multirow{2}{*}{$\begin{array}{l}K_{i}(\mathrm{~nm}) \\
{\left[{ }^{3} \mathrm{H}\right](+) \text {-Pent }}\end{array}$} & \multicolumn{3}{|c|}{ Effect $(100 \mu \mathrm{M})$} & \multirow[b]{2}{*}{ Notes } \\
\hline & & $6 \mathrm{hr}$ & $24 \mathrm{hr}$ & $72 \mathrm{hr}$ & \\
\hline Haloperidol & $2.13 \pm 0.72$ & A-B & $\mathrm{C}$ & C-D & $1 \mathrm{~d} / \mathrm{A}(30 \mu \mathrm{M})$ \\
\hline Reduced haloperidol & $2.50 \pm 0.56$ & A-B & $\mathrm{C}$ & D & \\
\hline HAL metabolite I (piperidine) & $87.9 \pm 4.7$ & $\mathrm{~N}$ & A & A & \\
\hline HAL metabolite III (carboxylic acid) & $>4000$ & $\mathbf{N}$ & $N$ & $\mathbf{N}$ & $\mathrm{N}(300 \mu \mathrm{M})$ \\
\hline Trifluoperidol & $7.46 \pm 0.94$ & $\mathbf{N}$ & A-B & $\mathrm{B}-\mathrm{C}$ & \\
\hline Fluphenazine & $175 \pm 33.9$ & A-B & $\mathrm{C}$ & $\mathrm{D}$ & \\
\hline Perphenazine & $22.7 \pm 0.59$ & A & $\mathrm{B}-\mathrm{C}$ & $\mathrm{D}$ & \\
\hline Trifluoperazine & $314 \pm 3.5$ & A & $\mathrm{B}-\mathrm{C}$ & $\mathrm{C}$ & \\
\hline Thioridazine & $433 \pm 51$ & $\mathbf{N}$ & A & B & $6 \mathrm{hr} / \mathrm{A}(300 \mu \mathrm{M})$ \\
\hline Spiperone & $876 \pm 148$ & $N$ & A & $\mathrm{B}-\mathrm{C}$ & \\
\hline Pimozide & $386 \pm 11$ & $\mathbf{N}$ & A & D & \\
\hline (-)-Butaclamol & $87.8 \pm 4.7$ & $\mathbf{N}$ & A-B & C-D & \\
\hline (+)-Butaclamol & $3008 \pm 668$ & $\mathbf{N}$ & $\mathbf{N}$ & $\mathbf{N}$ & \\
\hline Rimcazole & $407 \pm 100$ & $\mathbf{N}$ & A & A-B & $1 \mathrm{~d} / \mathrm{C}(300 \mu \mathrm{M})$ \\
\hline (-)-Sulpiride & $>10,000$ & $\mathbf{N}$ & $\mathbf{N}$ & $\mathbf{N}$ & $N(300 \mu \mathrm{M})$ \\
\hline Clozapine & $>10,000$ & $\mathrm{~N}$ & $\mathrm{~N}$ & $\mathrm{~N}$ & \\
\hline
\end{tabular}

Compounds were incubated with C6 glioma cells at a concentration of $100 \mu \mathrm{M}$. The effects were observed over time and scored at $6 \mathrm{hr}$ (or less), $24 \mathrm{hr}$, and $72 \mathrm{hr}$ using the letter code as described in Materials and Methods and text and shown in Figure 1. Where indicated under Notes, cells were also monitored at other concentrations of test ligand. All experiments were repeated at least three times, with similar results. Duplicate wells were used for each test compound in each experiment. The binding affinities of each compound at sigma sites labeled by $\left[{ }^{3} \mathrm{H}\right](+)$-pentazocine were determined as described in Materials and Methods using membranes prepared from C6 glioma cells. Test compound was incubated at 12 concentrations ranging from 0.05 to $10,000 \mathrm{nM}$ or from 0.5 to $100,000 \mathrm{~nm}$. $\mathrm{IC}_{50}$ values werc obtaincd using the iterative curve-fitting program GRAPHPAD INPLOT (San Diego, CA). $K$, values were then calculated from IC $\mathrm{C}_{50}$ values using the Cheng-Prusoff equation (Cheng and Prusoff, 1973) and a $K_{d}$ of $3.76 \mathrm{~nm}$ as determined in independent experiments by Scatchard analysis. $K$, values are the averages of two or three experiments, \pm SEM. Each experiment was carried out in duplicate. "HAL metabolite I" and "HAL metabolite III" refer to the piperidine and carboxylic acid metabolites of haloperidol, respectively. Reduced haloperidol, HAL metabolite I, and HAL metabolite III correspond to metabolites

$A, B$, and C, respectively, as described previously in Bowen et al. (1990).

tabolite failed to produce an effect. The rank order of potency to produce morphological effects was haloperidol = reduced haloperidol $>$ piperidine metabolite $\gg$ carboxylic acid metabolite. This is in excellent agreement with the rank order of binding affinity at sigma sites of $\mathrm{C} 6$ glioma cell membranes labeled by $\left[{ }^{3} \mathrm{H}\right](+)$-pentazocine.

These effects of various neuroleptics could not be due to the interaction of the compounds with dopamine $\mathrm{D}_{2}$ receptors since membranes from $\mathrm{C} 6$ glioma cells showed no specific binding of $\left[{ }^{3} \mathrm{H}\right](-)$-sulpiride (not shown). Furthermore, the findings with (-)-sulpiride, enantiomers of butaclamol, and haloperidol metabolites argue against a mechanism involving blockade of dopamine $\mathrm{D}_{2}$ receptors. Based on binding affinities at dopamine $\mathrm{D}_{2}$ receptors (Largent et al., 1987), (-)-sulpiride should show potent activity and (+)-butaclamol should be more active than (-)-butaclamol. Results with metabolites of haloperidol are also not consistent with a dopaminergic mechanism, since reduced haloperidol has 80 -fold lower affinity at dopamine $\mathrm{D}_{2}$ receptors compared to haloperidol, and the piperidine metabolite lacks aftinity for dopamine $\mathrm{D}_{2}$ receptors (Bowen et al., 1990).

\section{Effect of novel ethylene diamines and piperazines}

We have reported the synthesis and characterization of a novel class of sigma ligands based on the aryl ethylene diamine pharmacophore (Radesca et al., 1991; Bowen et al., 1992; de Costa et al., 1992a,b, 1993; He et al., 1993). These compounds exhibit high affinity and selectivity for sigma receptors. Table 2 shows the effect of representative aryl cyclohexane diamines, aryl ethylene diamines, aryl piperazines, and conformationally restricted aryl diamines on C6 glioma cells. All of the compounds, with the exception of BD1006, had high affinity at sigma receptors labeled by $\left[{ }^{3} \mathrm{H}\right](+)$-pentazocine. These compounds also exhibited the ability to affect the morphology and viability of cells. For the most part, the activity of the compounds was generally correlated with their affinity at sigma sites, with several of the compounds producing effects as early as $6 \mathrm{hr}$ after addition to culture. Many of these compounds also produced cell death by $3 \mathrm{~d}$ in culture. Exceptions to this were the aryl ethylene diamine BD1047, the aryl piperazines BD1073, BD1101, and SH322, and the conformationally restricted aryl diamine BD1018. These compounds, although active, were much less active than would be predicted by their sigma binding affinity. It should be pointed out that BD1008 (Table 2) is an aryl ethylene diamine that has both high sigma affinity and potent effects on cells. BD1006 (Table 2) is a structural fragment of BD1008 that lacks the 3,4dichlorophenyl moiety but that retains the diamine moiety. As shown, removal of the aromatic ring eliminated sigma binding activity and concomitantly eliminated the effect on cells at concentrations up to $300 \mu \mathrm{M}$. This shows that the morphologic and cytotoxic effect of these diamines is not simply the result of a nonspecific interaction of a polycationic species with membrane lipids or other cell components.

\section{Effect of ligands for other receptors, enzymes, and ion channels}

Because of the relatively high concentration of drug used in these experiments and the potential for nonspecific effects or effects via interaction of neuroleptics at other receptors, compounds that are agonists and antagonists at other neurotransmitter receptors were tested. These results are shown in Table 


\begin{tabular}{|c|c|c|c|c|c|}
\hline \multirow[b]{2}{*}{ Compound } & \multirow{2}{*}{$\begin{array}{l}K_{t}(\mathbf{n} \mathbf{)}) \\
{\left[{ }^{3} \mathrm{H}\right](+)-\text { Pent }}\end{array}$} & \multicolumn{3}{|c|}{ Effect $(100 \mu \mathrm{M})$} & \multirow[b]{2}{*}{ Notes } \\
\hline & & $6 \mathrm{hr}$ & $24 \mathrm{hr}$ & $72 \mathrm{hr}$ & \\
\hline BD737 & $1.99 \pm 0.54$ & A & $\mathrm{B}$ & $C-D$ & \\
\hline SH344 & $2.85 \pm 0.04$ & A-B & $\mathrm{C}-\mathrm{D}$ & $\mathrm{D}$ & \\
\hline JL II-147 & $0.89 \pm 0.2$ & A-B & C-D & $\mathrm{D}$ & \\
\hline LR 172 & $0.47 \pm 0.07$ & A & $\mathrm{B}-\mathrm{C}$ & $\mathrm{D}$ & \\
\hline BD 1139 & $2.41 \pm 0.82$ & A & $\mathrm{B}-\mathrm{C}$ & $\mathrm{D}$ & \\
\hline BD 1063 & $7.14 \pm 0.89$ & $\mathrm{~A}$ & $\mathrm{~B}-\mathrm{C}$ & $\mathrm{D}$ & \\
\hline BD 1008 & $1.24 \pm 0.25$ & A & $\mathrm{B}-\mathrm{C}$ & $\mathrm{D}$ & \\
\hline BD 1006 & $>10,000$ & $\mathrm{~N}$ & $\mathrm{~N}$ & $\mathrm{~N}$ & $\mathrm{~N}(300 \mu \mathrm{M})$ \\
\hline BD 1216 & $52.1 \pm 6.1$ & $\mathrm{~N}$ & $\mathrm{~A}$ & $\mathrm{~B}-\mathrm{C}$ & $6 \mathrm{hr} / \mathrm{B}-\mathrm{C}(300 \mu \mathrm{M})$ \\
\hline BD1047 & $0.6 \pm 0.28$ & $\mathbf{N}$ & A & A & $1 \mathrm{~d} / \mathrm{B}(300 \mu \mathrm{M})$ \\
\hline BD1073 & $0.12 \pm 0.01$ & $\mathrm{~N}$ & $\mathrm{~N}$ & A & $6 \mathrm{hr} / \mathrm{B}-\mathrm{C}(300 \mu \mathrm{M})$ \\
\hline BD1101 & $0.66 \pm 0.2$ & $\mathbf{N}$ & A & A & $1 \mathrm{~d} / \mathrm{B}(300 \mu \mathrm{M})$ \\
\hline SH 322 & $0.14 \pm 0.01$ & $\mathbf{N}$ & $\mathrm{N}$ & A & $1 \mathrm{~d} / \mathrm{B}(300 \mu \mathrm{M})$ \\
\hline BD 1018 & $10.8 \pm 1.8$ & $\mathrm{~N}$ & $\mathrm{~N}$ & $\mathrm{~N}$ & $6 \mathrm{hr} / \mathrm{B}-\mathrm{C}(300 \mu \mathrm{M})$ \\
\hline
\end{tabular}

Experiments were carried out as described in the Table 1 caption.

3. Agonists or antagonists at dopamine $D_{1}$, dopamine $D_{2}$, serotonin (5-HT, 5- $\mathrm{HT}_{1 \mathrm{~A}}, 5-\mathrm{HT}_{2}$ ), $\alpha 1$-adrenergic, $\alpha 2$-adrenergic, glutamate, NMDA (glutamate site, PCP site, and glycine site), GABA, opiate, and muscarinic cholinergic receptors, as well as the MAO inhibitor pargyline were without effect at concentrations up to $300 \mu \mathrm{M}$ over a period of $72 \mathrm{hr}$. The only receptor ligands tested that exhibited any morphological activity at 100 $\mu \mathrm{M}$ were the dopamine D2 agonist (+)-PPHT and the $\beta$-adrenergic antagonists $(-)$-propranolol and alprenolol. The cytochrome P-450 inhibitor SKF 525A showed weak activity only at $300 \mu \mathrm{M}$. However, while other "control" compounds had little or no affinity for sigma sites, (+)-PPHT, (-)-propranolol, alprenolol, and SKF 525A all had significant sigma binding affinity, which may account for their morphological activity.

Several ion channcl modulators were examined for sigma affinity and morphological effects at a concentration of $100 \mu \mathrm{M}$. The L-type $\mathrm{Ca}^{2+}$ channel blockers nitrendipine and diltiazem lacked sigma binding affinity and failed to produce any effect at $100 \mu \mathrm{M}$. $S(-)$-verapamil exhibited only weak sigma binding affinity and produced no effect. The L-type $\mathrm{Ca}^{2+}$ channel activator $S(-)$-Bay K 8644 was devoid of sigma affinity and showed no morphological effect. Veratridine and amiloride, $\mathrm{Na}^{+}$channel activator and inhibitors, respectively, lacked sigma affinity and failed to produce a morphological effect. The $\mathrm{K}^{+}$channel activator and inhibitor minoxidil and 4-aminopyridine, respectively, both lacked sigma binding affinity and were both devoid of morphological activity.

These results demonstrate that the morphological effects show a rather remarkable specificity for compounds that exhibit affinity for sigma receptors. The activity of novel ethylene diamine-related compounds that show both high affinity and high selectivity for sigma sites provides further support for mediation of these effects by sigma receptors.

\section{Effect of prototypic sigma ligands: DTG, (+)-3-PPP, and benzomorphans}

Table 4 shows the effect of DTG, $(+)-3-P P P,(+)$-pentazocine, and several other benzomorphans and morphinans on $\mathrm{C} 6 \mathrm{gli}-$ oma cells. Despite high sigma binding affinity, the prototypic sigma ligands DTG, $(+)$-3-PPP, and $(+)$-pentazocine failed to produce any effect on cells at $100 \mu \mathrm{M}$ in $3 \mathrm{~d}$ of culture. Even at $300 \mu \mathrm{M}, \mathrm{DTG}$ and ( + )-pentazocine failed to produce an effect, with (+)-3-PPP showing initial signs of an effect after $1 \mathrm{~d}$ of culture. Likewise, other enantiomeric benzomorphans such as SKF 10,047 and cyclazocine failed to produce an effect at up to $300 \mu \mathrm{M}$ over a period of up to $3 \mathrm{~d}$. An exception was the enantiomers of $N$-benzylnormetazocine ( $N$-benzyl-NM) (Carroll et al., 1992a), which produced a small effect at $300 \mu \mathrm{M}$ after $1 \mathrm{~d}$ of culture. The sigma-active morphinans dextrallorphan and dextromethorphan also failed to produce an effect at $100 \mu \mathrm{M}$, although they did produce a weak effect at $300 \mu \mathrm{M}$ at $3 \mathrm{~d}$ of culture. Levallorphan, (+)- and (-)-normetazocine, (+)-naltrexone, and $(+)$-etorphine, which are weak or inactive at sigma sites, were without effect on cells. Table 3 showed that (-)morphine and (-)-naltrexone were inactive at both sigma sites and at producing an effect on cells.

\section{Synergistic interaction of sigma ligands}

One possible reason for the inactivity of the prototypic sigma ligands and opiate-related compounds is that they may be antagonists or partial agonists at the sigma site responsible for the effect. However, preliminary experiments showed that $(+)-3-$ PPP and (+)-pentazocine did not attenuate the activity of BD737, but rather enhanced it. This apparent synergistic interaction between prototypic sigma ligands and BD737 was investigated further in experiments whose results are shown in Table 5. Here the effect of $30 \mu \mathrm{M} \mathrm{BD737}$ on the activity of various prototypic sigma and non-sigma compounds $(300 \mu \mathrm{M})$ was assessed at $6 \mathrm{hr}$ of drug exposure [24 hr for (+)-3-PPP]. Alone at a concentration of $30 \mu \mathrm{M}, \mathrm{BD} 737 \mathrm{had}$ no effect on cells in $6 \mathrm{hr}$ and caused only loss of fine processes (score of "A") after $24 \mathrm{hr}$. Table 5 shows that at $300 \mu \mathrm{M}$, enantiomers of $N$-benzylnormetazocine, pentazocine, and cyclazocine alone had no effect in $6 \mathrm{hr}$. However, in the presence of $30 \mu \mathrm{M}$ BD737, these compounds exhibited significant activity in $6 \mathrm{hr}$, causing effects ranging from loss of fine processes to changes in cell shape. Interestingly, it could be demonstrated under synergized conditions that (+)-pentazocine and $(+)$-cyclazocine were slightly more active than the corre- 
Table 3. Effect of miscellaneous receptor agonists, antagonists, enzyme inhibitors, and channel modulators

\begin{tabular}{|c|c|c|c|}
\hline Compound & Compound type & $\begin{array}{l}K_{i}(\mathrm{nM}) \\
{\left[{ }^{3} \mathrm{H}\right](+) \text {-Pent }}\end{array}$ & $\begin{array}{l}\text { Effect on } \\
\text { C6 cells } \\
\text { at } 72 \mathrm{hr} \\
\text { using } \\
300 \mu \mathbf{M}^{a}\end{array}$ \\
\hline Glutamate & Glutamate agonist & $>10,000$ & $\mathrm{~N}+$ \\
\hline NMDA & NMDA agonist & $>10,000$ & $\mathbf{N}$ \\
\hline PCP & NMDA channel blocker & $>10,000$ & $\mathrm{~N}$ \\
\hline$(+)-M K ~ 801$ & NMDA channel blocker & $>10,000$ & $\mathrm{~N}$ \\
\hline Kynurenic acid & NMDA glycine site & $>10,000$ & $\mathbf{N}$ \\
\hline Carbachol & Muscarinic agonist & $>10,000$ & $\mathbf{N}$ \\
\hline Atropine & Muscarinic antagonist & $>10,000$ & $\mathbf{N}$ \\
\hline Pirenzepine & Muscarinic antagonist & $>10,000$ & $\mathbf{N}$ \\
\hline (-)-Morphine & Opiate agonist & $>10,000$ & $\mathrm{~N}$ \\
\hline$(-)$-Naltrexone & Opiate antagonist & $>10,000$ & $\mathbf{N}$ \\
\hline$(+)$-SKF 38393 & $D_{1}$ agonist & $>10,000$ & $\mathrm{~N}^{*}$ \\
\hline$(+)-S C H 23390$ & $D_{1}$ antagonist & $>10,000$ & $\mathbf{N}$ \\
\hline$( \pm)-\mathrm{PPHT}$ & $\mathrm{D}_{2}$ agonist & $46.4 \pm 18.3$ & $A-B^{*}$ \\
\hline (-)-Sulpiride & $\mathrm{D}$, antagonist & $>10,000$ & $\mathrm{~N}$ \\
\hline (-)-Propranolol & $\beta$-Adrenergic antagonist & $499 \pm 5$ & $A-B^{*}$ \\
\hline Alprenolol & $\beta$-Adrenergic antagonist & $289 \pm 119$ & $A-B^{*}$ \\
\hline Prazosin & $\alpha_{1}$-Adrenergic antagonist & $>10,000$ & $\mathrm{~N}^{*}$ \\
\hline Yohimbine & $\alpha_{2}$-Adrenergic antagonist & $>10,000$ & $\mathrm{~N}$ \\
\hline Serotonin & 5-HT agonist & $>10,000$ & $\mathbf{N}$ \\
\hline$( \pm)-8-\mathrm{OH}$ DPAT & $5-\mathrm{HT}_{\mathrm{IA}}$ agonist & $1,414 \pm 21$ & $\mathrm{~N}$ \\
\hline Mianserin & $5-\mathrm{HT}_{2}>5-\mathrm{HT}_{1}$ antagonist & $>10,000$ & $\mathrm{~N}$ \\
\hline GABA & GABA agonist & $>10,000$ & $\mathrm{~N}$ \\
\hline SKF 525A & Cytochrome P-450 inhib. & $472 \pm 50$ & $\mathrm{~N}^{*}$ \\
\hline Pargyline & MAO-inhibitor & $>10,000$ & $\mathrm{~N}$ \\
\hline$S(-)$-Bay K 8644 & $\mathrm{Ca}^{2+}$ channel agonist & $>10,000$ & $\mathbf{N}$ \\
\hline Nitrendipine & $\mathrm{Ca}^{2+}$ channel blocker & $>10,000$ & $\mathbf{N}$ \\
\hline Diltiazem & $\mathrm{Ca}^{2+}$ channel blocker & $>10,000$ & $\mathbf{N}$ \\
\hline$S(-)$-Verapamil & $\mathrm{Ca}^{2+}$ channel blocker & $799 \pm 71$ & $\mathbf{N}$ \\
\hline Minoxidil & $\mathrm{K}^{+}$channel agonist & $>10,000$ & $\mathbf{N}$ \\
\hline 4-Aminopyridine & $\mathrm{K}^{+}$channel antagonist & $>10,000$ & $\mathbf{N}$ \\
\hline Veratridine & $\mathrm{Na}^{+}$channel agonist & $>10,000$ & $\mathrm{~N}$ \\
\hline Amiloride & $\mathrm{Na}^{+}$channel blocker & $>10,000$ & $N$ \\
\hline
\end{tabular}

Experiments were carried out as described in Table 1 caption.

" Compounds were tested at a concentration of $300 \mu \mathrm{M}$, except where indicated by ${ }^{*}$, which indicates $100 \mu \mathrm{M}$, and by + , which indicates $500 \mu \mathrm{M}$.

sponding (-)-enantiomers, consistent with sigma binding affinity at sigma-1-like receptors. Similar results were observed with (+)-3-PPP after observation for $24 \mathrm{hr}$. Alone at $300 \mu \mathbf{M},(+)-$ 3-PPP had no effect in $24 \mathrm{hr}$, and $30 \mu \mathrm{M}$ BD737 caused only withdrawal of cell processes (score of " $A$ "). However, the combination of $300 \mu \mathrm{M}(+)-3-P P P$ and $30 \mu \mathrm{M}$ BD737 produced significant cell rounding (score of " $\mathrm{B}$ ") in this $24 \mathrm{hr}$ time period. No synergism with $30 \mu \mathrm{M}$ BD737 could be observed over the $6 \mathrm{hr}$ period when $100 \mu \mathrm{M}$ of the prototypic compounds was used (not shown).

This shows a marked synergistic interaction between BD737 and prototypic sigma compounds, which at first glance appeared inactive. Importantly, compounds that lack sigma binding affinity (MK-801, atropine, morphine, NMDA, and glutamate) were inactive alone at $300 \mu \mathrm{M}$ and remained inactive in the presence of $30 \mu \mathrm{M}$ BD737 (Table 5). This further supports the notion that the effects are mediated specifically through sigma receptors.

\section{Effect of $p H$ on activity}

In the course of investigating medium requirements for the morphologic and cytotoxic effects of sigma ligands, it was discovered that the $\mathrm{pH}$ of the medium markedly affected the activity of the compounds. To investigate this systematically, the $\mathrm{pH}$ of the incubation medium was altered to be more alkaline (pH 8.3-8.5) or more acidic ( $\mathrm{pH} \mathrm{6.5-6.7)} \mathrm{than} \mathrm{the} \mathrm{normal} \mathrm{pH}$ of 7.2-7.4. These $\mathrm{pH}$ alterations alone had no pronounced effect on the cells over the $72 \mathrm{hr}$ period of observation. The effects of sigma compounds were determined and compared to untreated cells that were maintained under the same $\mathrm{pH}$ condition.

Alkaline $p H$. The results of the effect of $\mathrm{pH}$ on activity of three concentrations of sigma compounds are shown in Table 6 . For all compounds tested that had sigma binding affinity, raising the $\mathrm{pH}$ of the medium to $\mathrm{pH} 8.3-8.5$ increased the activity. The dose curves were effectively shifted to the left for these compounds. For example, at normal $\mathrm{pH}, 30 \mu \mathrm{M}$ reduced 
Table 4. Effects of prototypic sigma ligands and opiate-related compounds

\begin{tabular}{|c|c|c|c|c|c|}
\hline \multirow[b]{2}{*}{ Compound } & \multirow{2}{*}{$\begin{array}{l}K_{i}(\mathrm{~nm}) \\
{\left[{ }^{3} \mathrm{H}\right](+) \text {-Pent }}\end{array}$} & \multicolumn{3}{|c|}{ Effect $(100 \mu \mathrm{M})$} & \multirow[b]{2}{*}{ Notes } \\
\hline & & $6 \mathrm{hr}$ & $24 \mathrm{hr}$ & $72 \mathrm{hr}$ & \\
\hline DTG & $51.1 \pm 9.19$ & $\mathbf{N}$ & $\mathbf{N}$ & $\mathbf{N}$ & $\mathrm{N}(300 \mu \mathrm{M})$ \\
\hline$(+)-3-\mathrm{PPP}$ & $102 \pm 34$ & $\mathbf{N}$ & $\mathrm{N}$ & $\mathrm{N}$ & $1 \mathrm{~d} / \mathrm{A}(300 \mu \mathrm{M})$ \\
\hline (+)-Pentazocine & $5.3 \pm 1.12$ & $\mathbf{N}$ & $\mathrm{N}$ & $\mathrm{N}$ & $N(300 \mu \mathrm{M})$ \\
\hline (-)-Pentazocine & $39.9 \pm 2.99$ & $\mathbf{N}$ & $\mathbf{N}$ & $\mathbf{N}$ & $\mathrm{N}(300 \mu \mathrm{M})$ \\
\hline$(+)$-SKF 10,047 & $420 \pm 43$ & $\mathrm{~N}$ & $\mathrm{~N}$ & $\mathrm{~N}$ & $\mathrm{~N}(300 \mu \mathrm{M})$ \\
\hline (-)-SKF 10,047 & $1,917 \pm 113$ & $\mathbf{N}$ & $\mathbf{N}$ & $\mathbf{N}$ & $\mathrm{N}(300 \mu \mathrm{M})$ \\
\hline$(+)-N$-benzyl-NM & $3.63 \pm 0.88$ & $\mathbf{N}$ & $\mathbf{N}$ & $\mathbf{N}$ & $1 \mathrm{~d} / \mathrm{A}(300 \mu \mathrm{M})$ \\
\hline (-)- $N$-benzyl-NM & $92.5 \pm 10.5$ & $\mathbf{N}$ & $\mathbf{N}$ & $\mathrm{N}$ & $1 \mathrm{~d} / \mathrm{A}(300 \mu \mathrm{M})$ \\
\hline$(+)$-Cyclazocine & $45.9 \pm 2.20$ & $\mathbf{N}$ & $\mathbf{N}$ & $\mathbf{N}$ & $N(200 \mu M)$ \\
\hline (-)-Cyclazocine & $408 \pm 63$ & $\mathrm{~N}$ & $\mathrm{~N}$ & $\mathbf{N}$ & $N(200 \mu M)$ \\
\hline (+)-Deoxy-pentazocine & $2.50 \pm 0.11$ & $\mathbf{N}$ & $\mathrm{N}$ & $\mathbf{N}$ & $\mathrm{N}(300 \mu \mathrm{M})$ \\
\hline (-)-Deoxy-pentazocine & $40.2 \pm 8.48$ & $\mathbf{N}$ & $\mathrm{N}$ & $\mathrm{N}$ & $N(300 \mu \mathrm{M})$ \\
\hline Dextrallorphan & $81.3 \pm 6.16$ & $\mathbf{N}$ & $\mathrm{N}$ & $\mathrm{N}$ & $3 \mathrm{~d} / \mathrm{A}(300 \mu \mathrm{M})$ \\
\hline Levallorphan & $1632 \pm 284$ & $\mathbf{N}$ & $\mathrm{N}$ & $\mathbf{N}$ & $N(300 \mu \mathrm{M})$ \\
\hline Dextromethorphan & $714 \pm 86$ & $N$ & $\mathrm{~N}$ & $\mathbf{N}$ & $3 \mathrm{~d} / \mathrm{A}(300 \mu \mathrm{M})$ \\
\hline$(+)$-Normetazocine & $>10,000$ & $\mathrm{~N}$ & $\mathrm{~N}$ & $\mathbf{N}$ & $\mathrm{N}(300 \mu \mathrm{M})$ \\
\hline (-)-Normetazocine & $>10,000$ & $\mathbf{N}$ & $\mathbf{N}$ & $\mathbf{N}$ & $\mathrm{N}(300 \mu \mathrm{M})$ \\
\hline$(+)$-Naltrexone & $>10,000$ & $\mathrm{~N}$ & $\mathrm{~N}$ & $\mathrm{~N}$ & $\mathrm{~N}(300 \mu \mathrm{M})$ \\
\hline$(+)$-Etorphine & $>10,000$ & $\mathrm{~N}$ & $\mathrm{~N}$ & $\mathbf{N}$ & $\mathrm{N}(300 \mu \mathrm{M})$ \\
\hline
\end{tabular}

Experiments were carried out as described in the Table 1 caption. $N$-benzyl-NM, $N$-benzylnormetazocine.

haloperidol and fluphenazine produced withdrawal of fine processes only after $3 \mathrm{~d}$ of culture, whereas at more alkaline $\mathrm{pH}$ this effect occurred in $6 \mathrm{hr}$ at $30 \mu \mathrm{M}$. Also, in this series of experiments $100 \mu \mathrm{M}$ BD1073, SH322, BD1018, and BD1101 (which were less active than would be cxpected based on their sigma binding affinity as mentioned above) showed no significant effect in up to $3 \mathrm{~d}$ of culture at normal $\mathrm{pH}$, but caused initial withdrawal of process in only $6 \mathrm{hr}$ when cultured under alkaline conditions at $100 \mu \mathrm{M}$.

\section{Table 5. Effect of co-incubation of sigma and non-sigma ligands with} BD737

\begin{tabular}{lll} 
& \multicolumn{2}{c}{$6 \mathrm{hr}$ observation time } \\
\cline { 2 - 3 } Compound & & $300 \mu \mathrm{M}+$ \\
$30 \mu \mathrm{M}$ \\
$(+)-N$-henzyl-NM & $300 \mu \mathrm{M}$ & $\mathrm{BD} 737$ \\
$(-)-N$-benzyl-NM & $\mathrm{N}$ & $\mathrm{A}$ \\
$(+)-$ Pentazocine & $\mathrm{N}$ & $\mathrm{A}$ \\
$(-)$-Pentazocine & $\mathrm{N}$ & $\mathrm{A}-\mathrm{B}$ \\
(+)-Cyclazocine & $\mathrm{N}$ & $\mathrm{A}$ \\
$(-)$-Cyclazocine & $\mathrm{N}$ & $\mathrm{A}-\mathrm{B}$ \\
$(+)-3-P P P *$ & $\mathrm{~N}$ & $\mathrm{~A}$ \\
MK-801 & $\mathrm{N}$ & $\mathrm{B}$ \\
Atropine & $\mathrm{N}$ & $\mathrm{N}$ \\
(-)-Morphine & $\mathrm{N}$ & $\mathrm{N}$ \\
NMDA & $\mathrm{N}$ & $\mathrm{N}$ \\
L-Glutamate & $\mathrm{N}$ & $\mathrm{N}$ \\
& $\mathrm{N}$ & $\mathrm{N}$
\end{tabular}

C6 glioma cells were incubated with $300 \mu \mathrm{M}$ concentration of test compound in the absence or presence of $30 \mu \mathrm{M}$ BD737. Effects of test compound were then compared over time both to control cells that received no drug and to cells incubated with $30 \mu \mathrm{M}$ BD737 alone. The scores are expressed as the effect observed at $6 \mathrm{hr}[*, 24 \mathrm{hr}$ for (+)-3-PPP] according to the letter code described in Materials and Methods, text, and Figure 1. Score for $30 \mu \mathrm{M}$ BD737 alone was $6 \mathrm{hr}=\mathrm{N} ; 24$ $\mathrm{hr}=\mathrm{A}$. Experiments were repeated at least twice with similar results. Duplicate wells were used for each test compound in each experiment.
As shown in Table 4, prototypic sigma ligands such as DTG, $(+)$-3-PPP, and $(+)$-pentazocine showed little or no ability to affect cells, despite high sigma binding affinity. However, the activity of these compounds was dramatically enhanced at alkaline $\mathrm{pH}$. Notably, $100 \mu \mathrm{M}$ and $300 \mu \mathrm{M}$ concentrations of pentazocine enantiomers showed no effect in $3 \mathrm{~d}$ at $\mathrm{pH} 7.2-7.4$, but produced significant loss of processes as rapidly as $6 \mathrm{hr}$ at only $100 \mu \mathrm{M}$ under conditions of alkaline $\mathrm{pH}$. Likewise, enantiomers of $N$-benzylnormetazocine were active only at $300 \mu \mathrm{M}$ at normal $\mathrm{pH}$, showing withdrawal of processes after $24 \mathrm{hr}$. However, in alkaline $\mathrm{pH}$, withdrawal of processes and initial stages of rounding could be seen in $24 \mathrm{hr}$ at $100 \mu \mathrm{M}$ and in $6 \mathrm{hr}$ at $300 \mu \mathrm{M}$. The (+)-enantiomer of $\mathrm{N}$-benzylnormetazocine and (+)-pentazocine tended to show slightly greater activity than the corresponding (-)-enantiomers (alkaline conditions, $100 \mu \mathrm{M}$ and 300 $\mu \mathrm{M}$, respectively), although this enantioselectivity was marginal at best. (+)-3-PPP and DTG also showed enhancements in morphological activity by alkaline $\mathrm{pH}$, with DTG showing no activity at up to $300 \mu \mathrm{M}$ under normal $\mathrm{pH}$, but exhibiting initial withdrawal of processes after $24 \mathrm{hr}$ of exposure under alkaline conditions.

The enhancing effect of alkaline $\mathrm{pH}$ is demonstrated more dramatically in Table 7. As opposed to Table 6, which shows the time and degree of the first effect observed, Table 7 shows the state of the cells at the $72 \mathrm{hr}$ time point for all compounds. For compounds shown to produce strong morphological changes at $100 \mu \mathrm{M}$ under normal conditions (Tables 1, 2), the lower concentration was tested $(30 \mu \mathrm{M})$. For compounds with less efficacy, the higher concentration $(100 \mu \mathrm{M}$ or $300 \mu \mathrm{M})$ is shown. Under alkaline conditions, with the exception of DTG and BD1047, all sigma compounds killed the cells, whereas cells remained unaffected under normal pH conditions. DTG (300 $\mu \mathrm{M})$ and $\mathrm{BD} 1047(30 \mu \mathrm{M})$ caused initial withdrawal of processes under alkaline conditions. BD1047 at $100 \mu \mathrm{M}$ caused extensive rounding under normal conditions, and killed cells under alkaline conditions (not shown). It is noteworthy that under al- 
Table 6. Effect of pH on morphological activity

\begin{tabular}{|c|c|c|c|c|c|c|c|c|c|}
\hline \multirow[b]{2}{*}{ Compound } & \multicolumn{3}{|c|}{ pH 6.5-6.7 } & \multicolumn{3}{|c|}{ pH 7.2-7.4 } & \multicolumn{3}{|c|}{ pH 8.3-8.5 } \\
\hline & 30 & 100 & 300 & 30 & 100 & 300 & 30 & 100 & 300 \\
\hline Reduced haloperidol & $\mathrm{N}$ & $1 \mathrm{~d} / \mathrm{A}$ & $6 \mathrm{hr} / \mathrm{A}$ & $3 \mathrm{~d} / \mathrm{A}$ & $6 \mathrm{hr} / \mathrm{A}-\mathrm{B}$ & $6 \mathrm{hr} / \mathrm{D}$ & $6 \mathrm{hr} / \mathrm{A}$ & $6 \mathrm{hr} / \mathrm{B}$ & - \\
\hline Fluphenazine & $\mathrm{N}$ & $1 \mathrm{~d} / \mathrm{A}$ & $6 \mathrm{hr} / \mathrm{C}$ & $3 \mathrm{~d} / \mathrm{A}$ & $6 \mathrm{hr} / \mathrm{A}-\mathrm{B}$ & $6 \mathrm{hr} / \mathrm{D}$ & $6 \mathrm{hr} / \mathrm{A}$ & $6 \mathrm{hr} / \mathrm{C}-\mathrm{D}$ & - \\
\hline (-)-Butaclamol & - & - & - & - & $1 \mathrm{~d} / \mathrm{A}-\mathrm{B}$ & - & - & $1 \mathrm{~d} / \mathrm{B}-\mathrm{C}$ & - \\
\hline BD737 & $\mathrm{N}$ & $1 \mathrm{~d} / \mathrm{A}$ & $6 \mathrm{hr} / \mathrm{B}$ & $1 \mathrm{~d} / \mathrm{A}$ & $6 \mathrm{hr} / \mathrm{A}$ & $6 \mathrm{hr} / \mathrm{D}$ & $6 \mathrm{hr} / \mathrm{A}$ & $6 \mathrm{hr} / \mathrm{B}$ & - \\
\hline $\mathrm{BD} 1216$ & $\mathrm{~N}$ & $\mathrm{~N}$ & $\mathbf{N}$ & $\mathbf{N}$ & $1 \mathrm{~d} / \mathrm{C}$ & $6 \mathrm{hr} / \mathrm{B}-\mathrm{C}$ & $3 \mathrm{~d} / \mathrm{C}$ & $6 \mathrm{hr} / \mathrm{B}-\mathrm{C}$ & $6 \mathrm{hr} / \mathrm{D}$ \\
\hline BD1047 & $\mathrm{N}$ & $\mathbf{N}$ & $\mathbf{N}$ & $\mathrm{N}$ & $1 \mathrm{~d} / \mathrm{A}$ & $6 \mathrm{hr} / \mathrm{B}-\mathrm{C}$ & $\mathbf{N}$ & $6 \mathrm{hr} / \mathrm{B}$ & $6 \mathrm{hr} / \mathrm{D}$ \\
\hline BD 1073 & $\mathrm{~N}$ & $\mathrm{~N}$ & $\mathrm{~N}$ & $\mathrm{~N}$ & $\mathbf{N}$ & $6 \mathrm{hr} / \mathrm{B}-\mathrm{C}$ & $\mathrm{N}$ & $6 \mathrm{hr} / \mathrm{A}$ & $6 \mathrm{hr} / \mathrm{C}-\mathrm{D}$ \\
\hline SII322 & $\mathbf{N}$ & $\mathbf{N}$ & $1 \mathrm{~d} / \mathrm{A}-\mathrm{B}$ & $\mathbf{N}$ & $\mathbf{N}$ & $6 \mathrm{hr} / \mathrm{B}-\mathrm{C}$ & $\mathrm{N}$ & $6 \mathrm{hr} / \mathrm{A}$ & $6 \mathrm{hr} / \mathrm{C}-\mathrm{D}$ \\
\hline BD 1018 & $\mathbf{N}$ & $\mathbf{N}$ & $\mathbf{N}$ & $\mathbf{N}$ & $\mathrm{N}$ & $6 \mathrm{hr} / \mathrm{B}-\mathrm{C}$ & $\mathbf{N}$ & $6 \mathrm{hr} / \mathrm{A}$ & $6 \mathrm{hr} / \mathrm{D}$ \\
\hline BD1101 & $\mathbf{N}$ & $\mathrm{N}$ & $1 \mathrm{~d} / \mathrm{A}-\mathrm{B}$ & $\mathbf{N}$ & $\mathrm{N}$ & $6 \mathrm{hr} / \mathrm{A}-\mathrm{B}$ & $3 \mathrm{~d} / \mathrm{A}$ & $6 \mathrm{hr} / \mathrm{A}$ & $6 \mathrm{hr} / \mathrm{C}-\mathrm{D}$ \\
\hline DTG & - & $\mathbf{N}$ & $\mathbf{N}$ & - & $\mathbf{N}$ & $\mathrm{N}$ & - & $\mathbf{N}$ & $1 \mathrm{~d} / \mathrm{A}$ \\
\hline (+)-3-PPP & - & $\mathbf{N}$ & $N$ & - & $\mathrm{N}$ & $1 \mathrm{~d} / \mathrm{A}$ & - & $1 \mathrm{~d} / \mathrm{A}$ & $6 \mathrm{hr} / \mathrm{A}$ \\
\hline (+)-Pentazocine & - & $\mathbf{N}$ & $\mathrm{N}$ & - & $\mathrm{N}$ & $\mathbf{N}$ & - & $6 \mathrm{hr} / \mathrm{A}$ & $6 \mathrm{hr} / \mathrm{A}-\mathrm{B}$ \\
\hline (-)-Pentazocine & - & $\mathrm{N}$ & $\mathrm{N}$ & - & $\mathrm{N}$ & $\mathrm{N}$ & - & $6 \mathrm{hr} / \mathrm{A}$ & $6 \mathrm{hr} / \mathrm{A}$ \\
\hline (+)-N-benzyl-NM & - & $\mathrm{N}$ & $\mathrm{N}$ & - & $\mathrm{N}$ & $1 \mathrm{~d} / \mathrm{A}$ & - & $1 \mathrm{~d} / \mathrm{A}-\mathrm{B}$ & $6 \mathrm{hr} / \mathrm{A}-\mathrm{B}$ \\
\hline (-)- $N$-benzyl-NM & - & $\mathrm{N}$ & $\mathrm{N}$ & - & $\mathrm{N}$ & $1 \mathrm{~d} / \mathrm{A}$ & - & $1 \mathrm{~d} / \mathrm{A}$ & $6 \mathrm{hr} / \mathrm{A}-\mathrm{B}$ \\
\hline
\end{tabular}

C6 glioma cells were incubated with 30,100 , or $300 \mu \mathrm{M}$ concentrations of the indicated compound in media at pH $6.5-6.7$ (acidic conditions), pH 7.2-7.4 (normal conditions), or $\mathrm{pH}$ 8.3-8.5 (alkaline conditions). Media of various $\mathrm{pH}$ were obtained as described in Materials and Methods. Effects were scored at 6 hr, $1 \mathrm{~d}$, or $3 \mathrm{~d}$ using the letter code described in Materials and Methods. Figure 1 . In each case, effects were compared to control cells maintained at the same pH and time of incubation,

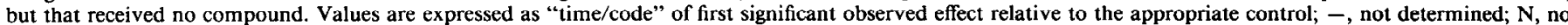

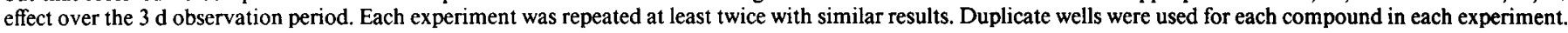

kaline conditions strong cytotoxic effects were obtained with only $30 \mu \mathrm{M}$ of some compounds in this $72 \mathrm{hr}$ period.

Importantly, like the synergistic interaction with BD737 described above (Table 5), raising the $\mathrm{pH}$ of the culture medium failed to increase the activity of compounds that lack affinity for sigma receptors. Table 8 shows that sigma receptor-inactive neurotransmitter agonists and antagonists, as well as ion channel activators and inhibitors, produced no effect at $72 \mathrm{hr}$ under

Table 7. Effect of alkaline pH on the action of sigma ligands

\begin{tabular}{lcll} 
& & \multicolumn{2}{l}{72 hr time point } \\
\cline { 3 - 4 } Compound & Conc. $(\mu \mathrm{M})$ & $\begin{array}{l}\text { Normal } \\
\mathrm{pH}\end{array}$ & $\begin{array}{l}\text { Alkaline } \\
\mathrm{pH}\end{array}$ \\
\hline Red. haloperidol & 30 & $\mathrm{~N}$ & $\mathrm{D}$ \\
Fluphenazine & 30 & $\mathrm{~A}$ & $\mathrm{D}$ \\
BD737 & 30 & $\mathrm{~A}$ & $\mathrm{D}$ \\
BD1216 & 30 & $\mathrm{~N}$ & $\mathrm{C}-\mathrm{D}$ \\
BD1047 & 30 & $\mathrm{~N}$ & $\mathrm{~A}$ \\
BD1073 & 100 & $\mathrm{~N}$ & $\mathrm{D}$ \\
SH322 & 100 & $\mathrm{~N}$ & $\mathrm{D}$ \\
BD1018 & 100 & $\mathrm{~N}$ & $\mathrm{D}$ \\
BD1101 & 100 & $\mathrm{~N}$ & $\mathrm{D}$ \\
DTG & 300 & $\mathrm{~N}$ & $\mathrm{~A}$ \\
$(+)-3-P P P$ & 300 & $\mathrm{~N}$ & $\mathrm{D}$ \\
$(+)-$ Pentazocine & 300 & $\mathrm{~N}$ & $\mathrm{D}$ \\
$(-)-P e n t a z 0 c i n e$ & 300 & $\mathrm{~N}$ & $\mathrm{D}$ \\
$(+)-N$-benzyl-NM & 100 & $\mathrm{~A}$ & $\mathrm{D}$ \\
$(-)-N$-benzyl-NM & 100 & $\mathrm{~N}$ & $\mathrm{D}$
\end{tabular}

C6 glioma cells were incubated with the indicated concentration of compound under normal $\mathrm{pH}$ conditions $(\mathrm{pH} 7.2-7.4)$ or alkaline conditions ( $\mathrm{pH} 8.3-8.5)$ as described in the Table 6 caption, except that the descriptive score for the cells at $72 \mathrm{hr}$ of exposure is given. Each experiment was repeated at least twice with similar results. Duplicate wells were used for each compound in each experiment. either normal or alkaline conditions. $S(-)$-Verapamil was the only exception. However, this compound also exhibited low but significant sigma binding affinity as shown in Table 3 . These data again support the mediation of these morphological effects by sigma receptors.

Acidic $p H$. Conversely, lowering the $\mathrm{pH}$ to 6.5-6.7 markedly reduced the activity of the sigma compounds (Tables 6,9 ). For example, Table 6 shows that while $100 \mu \mathrm{M}$ reduced haloperidol produced withdrawal of fine processes and some rounding in 6 hr at $100 \mu \mathrm{M}$ under normal $\mathrm{pH}$ conditions, it took $24 \mathrm{hr}$ to

Table 8. Effect of alkaline $\mathrm{pH}$ on the action of non-sigma ligands

\begin{tabular}{llll} 
& & \multicolumn{2}{l}{72 hr time point } \\
\cline { 3 - 4 } Compound & Conc. $(\mu \mathrm{M})$ & $\begin{array}{l}\text { Alka- } \\
\text { Normal } \\
\text { pH }\end{array}$ & $\begin{array}{l}\text { line } \\
\mathrm{pH}\end{array}$ \\
\hline$(-)$-Sulpiride & 300 & $\mathrm{~N}$ & $\mathrm{~N}$ \\
NMDA & 300 & $\mathrm{~N}$ & $\mathrm{~N}$ \\
$(+)$-MK 801 & 100 & $\mathrm{~N}$ & $\mathrm{~N}$ \\
Kynurenic acid & 100 & $\mathrm{~N}$ & $\mathrm{~N}$ \\
Carbachol & 300 & $\mathrm{~N}$ & $\mathrm{~N}$ \\
Atropine & 100 & $\mathrm{~N}$ & $\mathrm{~N}$ \\
Morphine & 100 & $\mathrm{~N}$ & $\mathrm{~N}$ \\
$S(-)$-Bay K 8644 & 100 & $\mathrm{~N}$ & $\mathrm{~N}$ \\
Nitrendipine & 100 & $\mathrm{~N}$ & $\mathrm{~N}$ \\
Diltiazem & 100 & $\mathrm{~N}$ & $\mathrm{~N}$ \\
$S(-)$-Verapamil & 100 & $\mathrm{~N}$ & $\mathrm{C}$ \\
Minoxidil & 100 & $\mathrm{~N}$ & $\mathrm{~N}$ \\
4-Aminopyridine & 100 & $\mathrm{~N}$ & $\mathrm{~N}$ \\
Amiloride & 100 & $\mathrm{~N}$ & $\mathrm{~N}$ \\
\hline
\end{tabular}

Experiments were carried out as described in the Table 7 caption. 
Table 9. Effect of acidic pH on the action of sigma ligands

\begin{tabular}{|c|c|c|c|c|}
\hline \multirow[b]{2}{*}{$\begin{array}{l}\text { Compound } \\
(300 \mu \mathbf{M})\end{array}$} & \multicolumn{2}{|c|}{$1 \mathrm{hr}$ time point } & \multicolumn{2}{|c|}{$24 \mathrm{hr}$ time point } \\
\hline & $\begin{array}{l}\text { Normal } \\
\text { pH }\end{array}$ & Acid $\mathrm{pH}$ & $\begin{array}{l}\text { Normal } \\
\mathrm{pH}\end{array}$ & $\begin{array}{l}\text { Acid } \\
\mathrm{pH}\end{array}$ \\
\hline BD737 & $\mathrm{C}$ & $\mathbf{N}$ & $\mathrm{D}$ & $\mathrm{B}-\mathrm{C}$ \\
\hline BD1073 & $\mathrm{C}$ & $\mathbf{N}$ & $\mathrm{D}$ & $\mathbf{N}$ \\
\hline BD1018 & $\mathrm{C}$ & $\mathbf{N}$ & $\mathrm{D}$ & $\mathbf{N}$ \\
\hline BD 1216 & $\mathrm{C}$ & $\mathrm{N}$ & $\mathrm{D}$ & $\mathrm{N}$ \\
\hline BD 1047 & $\mathrm{C}$ & $\mathrm{N}$ & $\mathrm{D}$ & $\mathrm{N}$ \\
\hline BD 1008 & A-B & $\mathbf{N}$ & $\mathrm{D}$ & $\mathbf{N}$ \\
\hline $\mathrm{SH} 344$ & $\mathrm{~B}-\mathrm{C}$ & $N$ & $\mathrm{D}$ & $\mathbf{N}$ \\
\hline SH384 & $\mathrm{B}-\mathrm{C}$ & $\mathbf{N}$ & $\mathrm{D}$ & $\mathbf{N}$ \\
\hline Reduced haloperidol & $\mathrm{C}$ & $\mathbf{B}$ & $\mathrm{D}$ & $\mathbf{A}-\mathbf{B}$ \\
\hline Fluphenazine & C-D & $\mathrm{C}-\mathrm{D}$ & $\mathrm{D}$ & D \\
\hline Perphenazine & $\mathrm{D}$ & $\mathrm{D}$ & $\mathrm{D}$ & $\mathrm{D}$ \\
\hline Trifluoperazine & $\mathbf{D}$ & D & $\mathrm{D}$ & $\mathrm{D}$ \\
\hline
\end{tabular}

The indicated compounds were incubated with $\mathrm{C} 6$ glioma cells at a concentration of $300 \mu \mathrm{m}$ under normal ( $\mathrm{pH} \mathrm{7.2-7.4)}$ or acidic ( $\mathrm{pH} 6.56 .7$ ) conditions. The concentration of $300 \mu \mathrm{M}$ was used to produce a robust effect of the test compounds. Cells were then observed by microscopy at $1 \mathrm{hr}$ and $24 \mathrm{hr}$ after drug addition and given a letter score as described in Materials and Methods, text, and Figure 1. Experiments were repeated twice with similar results.

produce only initial withdrawal of processes at this concentration under acidic conditions. Similarly, $30 \mu \mathrm{M}$ BD737 caused initial withdrawal of processes in $1 \mathrm{~d}$ under normal conditions, whereas under acidic conditions $30 \mu \mathrm{M}$ BD737 produced no effect in up to $3 \mathrm{~d}$ of culture.

Table 9 shows the state of cells at 1 and $24 \mathrm{hr}$, with all compounds at $300 \mu \mathrm{M}$. At low $\mathrm{pH}$, cells could survive in the presence of $300 \mu \mathrm{M}$ of some compounds that produced rapid cell death over the same time period under normal conditions. At $300 \mu \mathrm{M}$, all compounds shown caused at least extensive cell rounding and, in some cases, cell death in $1 \mathrm{hr}$ or less when cultured under normal $\mathrm{pH}$ conditions. After $24 \mathrm{hr}$ of culture at normal $\mathrm{pH}, 300 \mu \mathrm{M}$ of all compounds killed the cells. Culture under acidic conditions afforded complete or near complete protection from these effects. Notably, $300 \mu \mathrm{M}$ BD1008, BD 1018, BD1047, BD1073, SH344, and SH384 produced no noticeable effect on cells under acidic conditions even after $1 \mathrm{~d}$ of culture, with BD737 and reduced haloperidol also being markedly attenuated. Clear exceptions to this were fluphenazine, perphenazine, and trifluoperazine. Table 9 shows that the action of 300 $\mu \mathrm{M}$ of these compounds was not significantly attenuated by low $\mathrm{pH}$ at either the $1 \mathrm{hr}$ or $24 \mathrm{hr}$ time point. However, Table 6 shows that the action of $30 \mu \mathrm{M}$ and $100 \mu \mathrm{M}$ fluphenazine was attenuated by low $\mathrm{pH}$ when compared to normal conditions.

\section{Reversibility of the effect}

Experiments were conducted to test the reversibility of the effects of sigma ligands on cellular morphology. C6 glioma cells were treated with $100 \mu \mathrm{M}$ or $300 \mu \mathrm{M}$ concentrations of sigma compounds for $3 \mathrm{hr}$. Medium was then removed and the cells washed once with fresh medium containing no drug. After addition of normal medium without drug, the cells were observed 18-24 hr later to assess survival. Results are shown in Table 10. At a concentration of $100 \mu \mathrm{M}$, all compounds tested produced at least withdrawal of processes in the $3 \mathrm{hr}$ time period. Replacement of medium with medium without drug resulted in resumption of normal shape.
Table 10. Reversibility of the morphological effect of sigma compounds

\begin{tabular}{|c|c|c|c|c|}
\hline \multirow[b]{2}{*}{ Compound } & & \multicolumn{2}{|c|}{$300 \mu \mathrm{M})$} \\
\hline & $3 \mathrm{hr}$ & $\begin{array}{l}18-24 \\
\text { hr } \\
\text { (post- } \\
\text { wash) }\end{array}$ & $3 \mathrm{hr}$ & $\begin{array}{l}18-24 \\
\text { hr } \\
\text { (post- } \\
\text { replat- } \\
\text { ing) }\end{array}$ \\
\hline BD737 & A & $\mathbf{N}$ & $\mathrm{C}$ & $\mathbf{N}$ \\
\hline BD 1008 & A-B & $N$ & $\mathrm{C}$ & $\mathrm{N}$ \\
\hline BD 1047 & A-B & $\mathrm{N}$ & $\mathrm{C}$ & $\mathrm{N}$ \\
\hline BD 1073 & $\mathrm{~A}$ & $\mathbf{N}$ & $\mathrm{C}$ & $N$ \\
\hline SH344 & A-B & $\mathrm{N}$ & $\mathrm{B}-\mathrm{C}$ & $\mathrm{N}$ \\
\hline SH384 & $A-B$ & $\mathbf{N}$ & $\mathrm{B}-\mathrm{C}$ & $\mathbf{N}$ \\
\hline Reduced haloperidol & A-B & $\mathrm{N}$ & $\mathrm{C}$ & $\mathrm{N}$ \\
\hline Fluphenazine & A-B & $\mathrm{N}$ & C-D & $\mathrm{D}$ \\
\hline Perphenazine & A-B & $\mathrm{N}$ & C-D & $\mathrm{D}$ \\
\hline Trifluoperazine & A-B & $\mathbf{N}$ & C-D & $\mathrm{D}$ \\
\hline
\end{tabular}

C6 glioma cells were incubated in normal medium with either $100 \mu \mathrm{M}$ or $300 \mu \mathrm{M}$ of test drug for a period of $3 \mathrm{hr}$ and scored using the letter code. Upon incubation with $100 \mu \mathrm{M}$ compound, the cells were altered, but remained attached. Medium was then carefully aspirated from the well, the attached cells washed once, and then the well refilled with fresh medium containing no drug. In the case of cells incubated with $300 \mu \mathrm{M}$ test compound, most of the cells were round and either floating or weakly attached. After gentle detachment of cells by repeated pipetting, medium containing floating cells was aspirated and the cells recovered by centrifugation at $1000 \mathrm{rpm}$ for $5 \mathrm{~min}$. Cells were washed by resuspension in fresh medium with no drug and centrifugation. Cells were then resuspended in fresh medium containing no drug and replated onto fresh wells. After 18-24 hr, cells exposed to both concentrations of test ligand were observed microscopically and scored.

The $300 \mu \mathrm{M}$ dose was used to ensure a rapid and vigorous acute effect. All compounds tested produced extensive rounding of cells during the $3 \mathrm{hr}$. At this stage, cells were either floating or weakly attached to the plate. Cells were recovered by centrifugation, washed, and replated in fresh normal medium without drug. After 18-24 hr, cells were alive and at various stages of normal development (Table 10). This is shown photographically for $300 \mu \mathrm{M}$ reduced haloperidol and BD737 in Figures 2 and 3 , respectively. Soon after removal of drug and replating, it can be seen that cells began to extend processes in the normal manner and eventually attained normal morphology. Figures 2 and 3 also emphasize the point that sigma ligands of very different structural classes produced the same effect on the cells.

Most of the sigma ligands produced a reversible morphological effect at both the $100 \mu \mathrm{M}$ and $300 \mu \mathrm{M}$ concentration. However, the phenothiazine-type neuroleptics were an exception. Table 10 shows that cells exposed to $300 \mu \mathrm{M}$ fluphenazine, trifluoperazine, or perphenazine failed to recover from the pretreatment, whereas cells exposed to the $100 \mu \mathrm{M}$ concentration recovered completely.

\section{Effect of sigma compounds on other cell lines}

Table 11 shows the effect of representative compounds on other cell lines tested under normal conditions of pH. The neuroblastomas SK-N-SH and SH-SY5Y, NCB-20 hybridoma, the neuroblastoma-glioma hybrid NG108-15, and the peripheral tissue-derived cell lines COS-7 (kidney), MRS-5 (lung), and PC12 (adrenal medulla) all responded in a similar manner to sigma compounds. It should be noted that while the actual morphological changes apparent in the neuroblastomas, hybridomas, and $\mathrm{PC} 12$ cell generally resembled those described for C6 glioma, changes observed in the COS-7 and MRS-5 were 
Table 11. Effects of sigma and non-sigma ligands on other cell lines

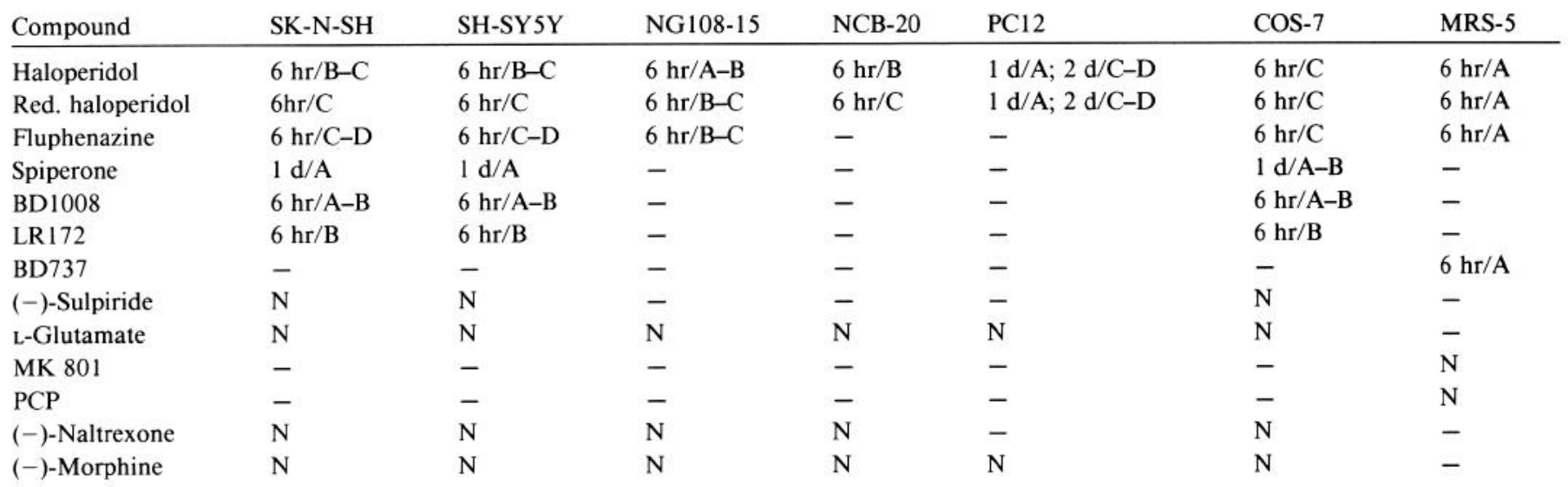

The indicated cell lines were incubated with $100 \mu \mathrm{M}$ test compound (500 $\mu \mathrm{M}$ for glutamate). Effects were scored and values expressed as "time/code" for the first significant observed effect at 6,24 , or $72 \mathrm{hr}$, except for PC12 cells, where effects at $48 \mathrm{hr}$ are also noted. Culture conditions for each cell line were as described in Materials and Methods. Experiments were repeated at least twice, with similar results. Duplicate wells were used for each compound. - , not determined.
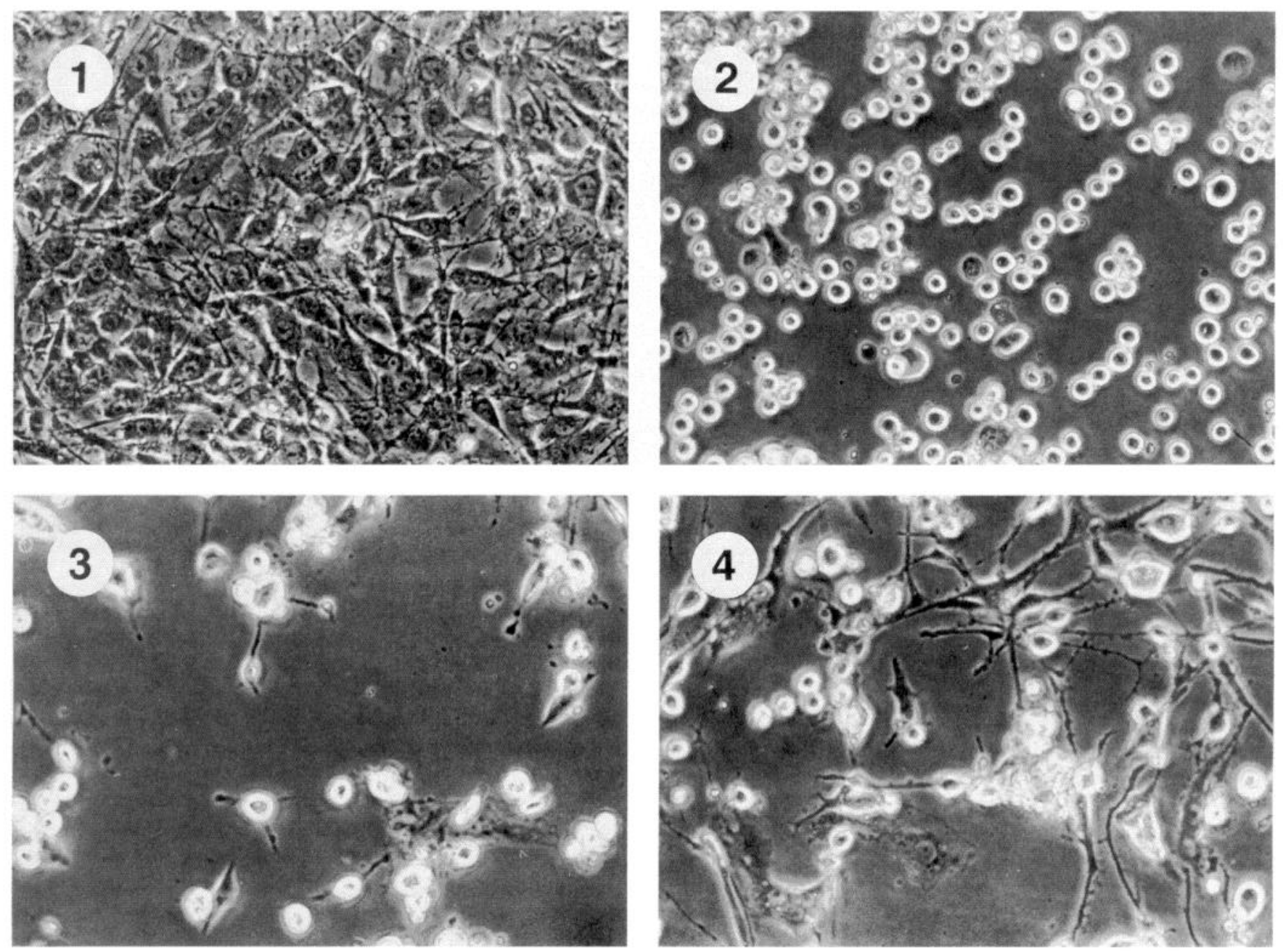

Figure 2. Reversibility of effect of reduced haloperidol on C6 glioma cells. C6 glioma cells were incubated in normal medium in the absence or presence of $300 \mu \mathrm{M}$ reduced haloperidol for a period of $3 \mathrm{hr}$. Floating cells were then harvested and washed by centrifugation as described in the caption to Table 10. Following replating in fresh medium, cells were observed at various times and photographed. 1 , Appearance of C6 glioma cells before exposure to reduced haloperidol. 2, Cells after exposure to $300 \mu \mathrm{M}$ reduced haloperidol for $3 \mathrm{hr}$. 3, Cells in 2 at $3 \mathrm{hr}$ after harvest, washing, and replating in fresh medium without sigma ligand. 4 , Cells in 2 at $18 \mathrm{hr}$ after replating. 

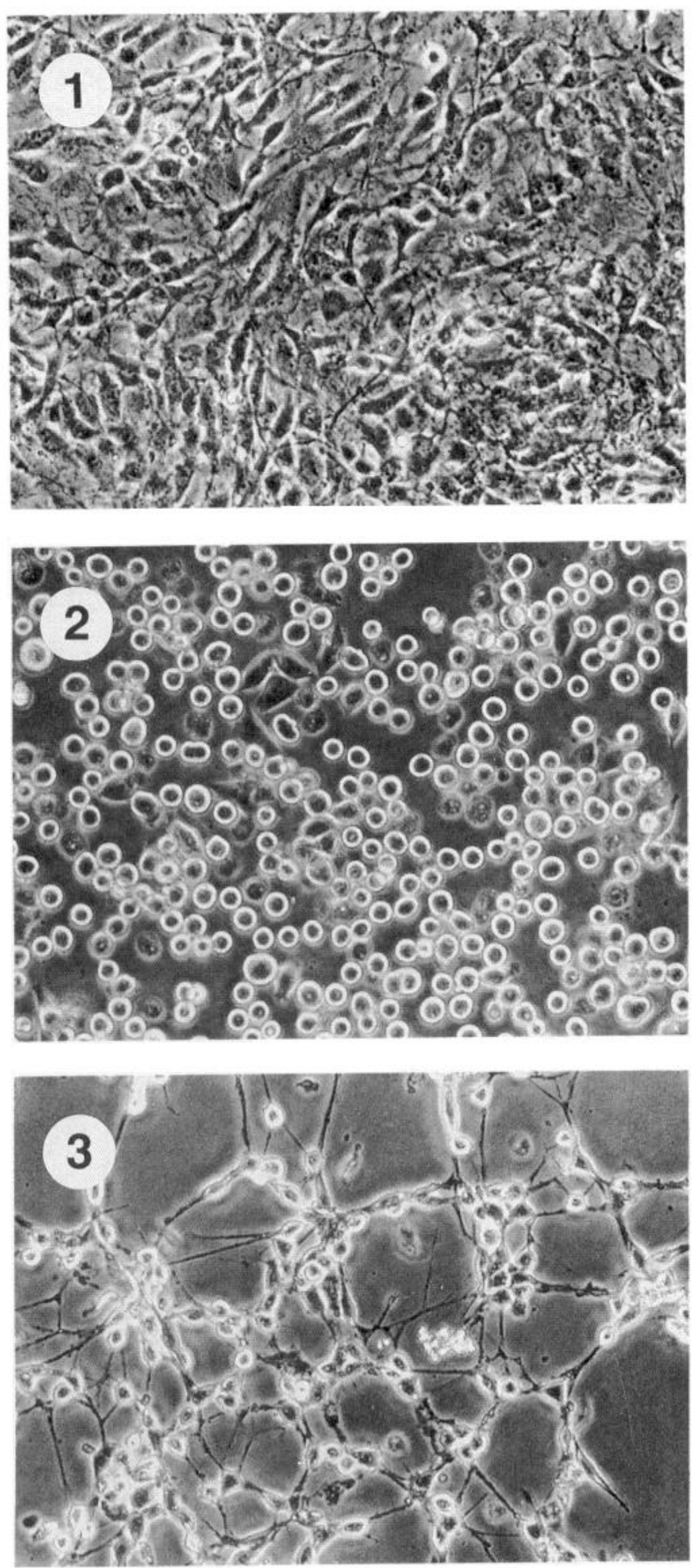

Figure 3. Reversibility of effect of BD737 on C6 glioma cells. C6 glioma cells were incubated in normal medium in the absence or presence of $300 \mu \mathrm{M}$ BD737 for a period of $3 \mathrm{hr}$. Cells were then treated as described in the caption to Table 10 and legend to Figure 2. 1, Appearance of $\mathrm{C} 6$ glioma cells before exposure to BD737. 2, Cells after exposure to $300 \mu \mathrm{M}$ BD737 for $3 \mathrm{hr}$. 3, Cells in 2 at $18 \mathrm{hr}$ after harvest, washing, and replating in fresh medium without BD737. different since these cells lack processes and instead have cytoplasmic filopodia.

With the exception of $\mathrm{PC} 12$ cells, haloperidol, reduced haloperidol, and fluphenazine $(100 \mu \mathrm{M})$ produced effects in $6 \mathrm{hr}$ in all cells tested. Also, BD737, BD1008, and LR172 were active in the cell lines tested. In the case of differentiated PC1 2 cells, which have highly developed, neuron-like processes, the effects of $100 \mu \mathrm{M}$ haloperidol and reduced haloperidol appeared somewhat delayed relative to other cell types. These included destruction of growth cones and swelling of processes (score "A") as early effects occurring after $24 \mathrm{hr}$ of culture. After $48 \mathrm{hr}$, cultures consisted of rounded cells that were in the process of detaching, and many floating and dying cells (score "C-D"). As with $\mathrm{C} 6$ glioma cells, ligands for dopamine $\mathrm{D}_{2}$, opiate, phencyclidine (PCP), and glutamate receptors (all of which lack sigma affinity) were inactive in all cell lines tested.

\section{Discussion}

Sigma ligands from various structural classes produced marked changes in the morphology and viability of $\mathrm{C} 6$ glioma cells and other cell lines in culture. Due to the qualitative nature of this assay, it was not possible in this study to determine the $\mathrm{ED}_{50}$ concentration of a given compound to produce morphological effects. Therefore, an absolute correlation of activity to receptor binding affinity could not be made. However, within these limits and with certain specific exceptions as described below, the rank order of potency of compounds to produce these effects corresponded roughly with rank order of binding affinity at $\mathrm{C} 6$ glioma sigma receptors labeled by $\left[{ }^{3} \mathrm{H}\right](+)$-pentazocine. At a given concentration, compounds with higher binding affinity tended to produce earlier and more pronounced effects, whereas compounds with lower sigma affinity had delayed effects on the cells. The effects of sigma ligands on the cells was reversible, with cells surviving after attaining a round shape if drug-containing medium was replaced with fresh medium after at least $3 \mathrm{hr}$ of preexposure. Survival of cells after longer periods of drug exposure was not tested.

A point of concern is the discrepancy between sigma binding affinity and the doses of sigma compounds required to produce effects. Under normal culture conditions, the lowest dose for any compound to produce an effect over the $3 \mathrm{~d}$ observation period was $30 \mu \mathrm{M}$. This is despite the nanomolar binding affinities for all active sigma compounds as measured in competition assays with $\left[{ }^{3} \mathrm{H}\right](+)$-pentazocine. The most likely explanation for this is that the binding assays were carried out under very different assay conditions compared to the morphological assays. When binding of $30 \mathrm{~nm}\left[{ }^{3} \mathrm{H}\right](+)$-pentazocine to $\mathrm{C} 6$ glioma cell membranes was assayed under the same conditions of medium, $\mathrm{pH}$, and temperature used to carry out morphological experiments, the level of specific binding was an order of magnitude lower compared to that in $50 \mathrm{~mm}$ Tris- $\mathrm{HCl}, \mathrm{pH} \mathrm{8.0,} \mathrm{at}$ $25^{\circ} \mathrm{C}$. This suggests the possibility that sigma ligands have reduced affinity under cell culture conditions. Furthermore, $\left[{ }^{3} \mathrm{H}\right](+)$-pentazocine competition studies were carried out using cell membranes, whereas morphological studies were carried out using intact cells. This could also contribute to discrepancies in potency versus binding affinity.

Because such high sigma ligand concentrations were needed to produce effects, an extensive study was made of non-sigma ligands to determine specificity. Compounds that have high affinity at other neurotransmitter receptors or enzymes but that lack sigma affinity failed to produce effects at concentrations up 
to $300 \mu \mathrm{M}$. Table 3 shows that the only "control" compounds that produced an effect were those that exhibited sigma binding affinity. These results show that the effects of compounds on cells are not due to a nonspecific mechanism or an artifact that is the result of using high ligand concentrations. This is further suggested by the fact that the morphologically active compounds are from several different structural classes, making a nonspecific effect less likely. $\Lambda$ common property of these different structural classes is affinity for sigma receptors. Taken together, these data strongly support the notion that these morphological effects are mediated by sigma sites.

The results also show that interaction of sigma compounds (particularly neuroleptics) at other receptors could not produce this effect. Although the presence of other neurotransmitter receptors on $\mathrm{C} 6$ glioma cells was not investigated in detail in this study, the cells did exhibit substantial levels of specific binding of $\left[{ }^{3} \mathrm{H}\right]$ dihydroalprenolol $(174 \mathrm{fmol} / \mathrm{mg}$ protein at $1.5 \mathrm{~nm})$ and $\left[{ }^{3} \mathrm{H}\right]$ prazosin $(141 \mathrm{fmol} / \mathrm{mg}$ protein at $3 \mathrm{~nm})$, and low but significant levels of $\left[{ }^{3} \mathrm{H}\right] \mathrm{ketanserin}(16.1 \mathrm{fmol} / \mathrm{mg}$ protein at $2 \mathrm{nM}$ ) and $\left[{ }^{3} \mathrm{H}\right]$ TCP $(27.7 \mathrm{fmol} / \mathrm{mg}$ protein at $5 \mathrm{~nm})$ binding, which are ligands for $\beta$-adrenergic, $\alpha 1$-adrenergic, serotonin $5-\mathrm{HT}_{2}$, and PCP/NMDA receptors, respectively. Radioligands for 5-HT (2 $\mathrm{nM}\left[{ }^{3} \mathrm{H}\right]$ serotonin), $\alpha 2$-adrenergic (2.5 $\mathrm{nM}\left[{ }^{3} \mathrm{H}\right]$ clonidine), opiate $\left(0.5 \mathrm{nM}\left[{ }^{3} \mathrm{H}\right]\right.$ etorphine $)$, muscarinic cholinergic $\left[1 \mathrm{nM}\left[{ }^{3} \mathrm{H}\right](-)-\right.$ quinuclidinyl benzilate $]$, and dopamine $\mathrm{D}_{2}\left[5 \mathrm{nM}\left[{ }^{3} \mathrm{H}\right](-)\right.$-sulpiride] showed little or no specific binding to membranes from C6 glioma cells. Despite the apparent presence of $5-\mathrm{HT}_{2}, \beta$-adrenergic, and $\alpha 1$-adrenergic receptors on $\mathrm{C} 6$ glioma cells, blockade of these receptors, which could possibly occur with the use of high concentrations of the neuroleptics, did not play a role in the effect since specific, high-affinity antagonists for these receptors did not produce potent effects (Table 3 ).

The results obtained with ion channel modulators show that possible interaction of sigma compounds with $\mathrm{Na}^{+}, \mathrm{K}^{+}$, or $\mathrm{Ca}^{2+}$ channels could not account for their morphological effects. Neither activators nor inhibitors of these channels showed any morphological effects over the $72 \mathrm{hr}$ observation period at a concentration of $100 \mu \mathrm{M}$. The inactivity of ion channel modulators is particularly germane since it has been suggested that some types of sigma receptors may be components of or allosteric modulators of $\mathrm{K}^{+}$or $\mathrm{Ca}^{2+}$ channels (Rothman et al., 1991; Wu et al., 1991; Paul et al., 1993). Furthermore, with the exception of $S(-)$-verapamil, these modulators all lacked affinity for sigma sites labeled by $\left[{ }^{3} \mathrm{H}\right](+)$-pentazocine in $\mathrm{C} 6$ glioma cell membranes. $S(-)$-verapamil exhibited only weak affinity for sigma binding sites. Thus, the lack of morphological effects of these compounds again supports the notion that actions of sigma receptor-active compounds are mediated by their specific interaction with sigma sites.

Despite their high sigma binding affinity, the prototypic sigma ligands DTG, (+)-3-PPP, (+)-pentazocine, and other sigmaactive benzomorphans and morphinans appeared inactive or only weakly active in up to $72 \mathrm{hr}$ of culture. These compounds did not appear to be acting as antagonists at the sigma site mediating the effect, since they failed to block or attenuate the action of $100 \mu \mathrm{M}$ BD737 (data not shown). Surprisingly, these compounds were found to act synergistically with a subeffective dose of BD737 to produce significant effects in $6 \mathrm{hr}$ of exposure to cells. This was true synergism since neither $30 \mu \mathrm{M}$ BD737 alone nor $300 \mu \mathrm{M}$ of the prototypic ligand alone showed any effect in this $6 \mathrm{hr}$ time frame. In fact, enantiomers of pentazocine and cyclazocine showed no effect for up to $3 \mathrm{~d}$ at $300 \mu \mathrm{M}$ and
$200 \mu \mathrm{M}$, respectively (Table 4). This shows that $30 \mu \mathrm{M}$ BD737 markedly enhances the activity of these compounds (or vice versa). Importantly, only compounds that exhibited sigma binding affinity showed the ability to synergize with BD737. Compounds lacking sigma affinity remained inactive even in the presence of $30 \mu \mathrm{M}$ BD737. This strongly supports mediation of these effects by sigma receptors.

Another manipulation of incubation conditions that clicited activity in these apparently inactive sigma compounds was raising the $\mathrm{pH}$ of the culture medium. Increasing the $\mathrm{pH}$ from the range 7.2-7.4 to 8.3-8.5 caused a marked leftward shift in the dose curves $(30 \mu \mathrm{M}, 100 \mu \mathrm{M}, 300 \mu \mathrm{M})$ for all active sigma compounds (Tables 6,7 ). This was most dramatic for the compounds that appeared under normal $\mathrm{pH}$ conditions to be much less active than their sigma binding affinity would predict. This included the novel compounds BD1073, SH322, BD1018, and BD1 101. Even more dramatic was the increase in activity of the prototypic sigma compounds DTG, (+)-3-PPP, (+)-pentazocine, and other benzomorphans. However, raising the $\mathrm{pH}$ did not improve the activity of compounds that lacked affinity for sigma receptors (Table 8). Even after $3 \mathrm{~d}$ of exposure under alkaline conditions and concentration of 100 or $300 \mu \mathrm{M}$, sigmainactive compounds produced no effect. It is noteworthy that $S(-)$-verapamil, the only ion channel modulator to exhibit any sigma binding affinity (Table 3 ), was also the only channel modulator to produce an effect under alkaline conditions. These data confirm the specificity of these morphologic and cytotoxic effects for sigma ligands.

Conversely, lowering the $\mathrm{pH}$ generally decreased the ability of sigma compounds to change cell morphology (Tables 6, 9). Cells at low $\mathrm{pH}$ showed no response in the presence of compounds (up to $300 \mu \mathrm{M}$ ) that produced complete cell rounding or cell death over the same time course at normal $\mathrm{pH}$. The ability of low $\mathrm{pH}$ to allow cell survival in the presence of even high concentrations of sigma ligands tends to argue against a general toxicity of the compounds. Thus, the low $\mathrm{pH}$ condition represents a way to "antagonize" the effect of the sigma compound and shows that simple contact of the compound with the cells alone cannot produce the morphological changes and toxicity.

Taken together, the synergism data and the effect of $\mathrm{pH}$ indicate that ligands with affinity for sigma receptors can be divided into distinct classes with respect to their morphological and cytotoxic effects: (1) "high-efficacy" sigma ligands, whose activity is apparent under normal conditions and is generally in line with sigma binding affinity; (2) "intermediate-efficacy" sigma ligands, which show significant activity under normal conditions, but with a degree that is much less than would be predicted from sigma binding affinity; and (3) "low-efficacy" sigma ligands whose activity is only apparent when synergized with another sigma ligand or when the $\mathrm{pH}$ of the medium is in the alkaline range. The neuroleptics and most of the novel ethylene diamine-related compounds would be "high-efficacy" ligands, whereas DTG, (+)-3-PPP, (+)-pentazocine, and other related benzomorphans would be in the class of "low-efficacy" sigma compounds. Compounds such as BD1047, BD1073, SH322, BD1018, and BD1101 would be examples of sigma ligands with "intermediate efficacy." Such a classification involving sigma ligands with a range of efficacies would explain the apparent discrepancies when various individual compounds are compared with respect to morphologic activity versus sigma binding affinity.

The synergistic effect of BD737 in combination with other 
sigma ligands is difficult to explain on the basis of a single sigma binding site. It is possible that there may be some type of allosteric interaction of these ligands at sigma sites whereby one ligand enhances the binding of the other. This type of positive allosteric interaction has been demonstrated for phenytoin and ropizine at brain sigma sites labeled by $\left[{ }^{3} \mathrm{H}\right]$ dextromethorphan, $\left[{ }^{3} \mathrm{H}\right](+)-3-P P P$, and $\left[{ }^{3} \mathrm{H}\right](+)$-pentazocine (Musacchio et al., 1989a; DeHaven-Hudkins et al., 1993), and liver sigma sites labeled with $\left[{ }^{3} \mathrm{H}\right](+)$-SKF 10,047 (McCann and Su, 1991). Also, allosteric structural models of sigma receptors have been suggested (Bowen et al., 1989; Rothman et al., 1991). However, there was no evidence for a positive allosteric interaction based on binding studies in $\mathrm{C} 6$ glioma cell membranes, since BD737 did not enhance $\left[{ }^{3} \mathrm{H}\right](+)$-pentazocine binding and inhibited binding in a monophasic manncr.

An alternative explanation is that there is more than one type of sigma receptor site involved in this effect. We have used $\left[{ }^{3} \mathrm{H}\right](+)$-pentazocine binding (sigma- 1 sites) in an attempt to correlate potency to sigma affinity. However, C6 glioma cells also contain a high density of sigma- 2 receptors (Vilner and Bowen, 1992), in addition to an as yet uncharacterized lowaffinity binding site for $\left[{ }^{3} \mathrm{H}\right](+)$-pentazocine that does not appear to be present in brain tissue (Vilner et al., 1992 and unpublished observations). We have also identified a unique sigma-like binding site for the iodinated aryl ethylene diamine [ ${ }^{125}$ I]SH344, which has properties that differ in some ways from either sigma-1 or sigma-2 sites (Lee et al., 1992 and unpublished observations; He et al., 1993). It is possible, therefore, that any of these other sigma-like sites, alone or in combination with sigma-1 sites labeled by $\left[{ }^{3} \mathrm{H}\right](+)$-pentazocine, could mediate the observed morphological and cytotoxic effects.

The effect of $\mathrm{pH}$ on activity has a number of possible explanations. It has been demonstrated that sigma binding is enhanced at higher $\mathrm{pH}$ (Largent et al., 1987). The high $\mathrm{pH}$ optimum for binding suggests that it is the deprotonated form of the sigma ligand that interacts with the receptor. $\left[{ }^{3} \mathrm{H}\right](+)$-Pentazocine binding to $\mathrm{C} 6$ glioma cell membranes was progressively increased going from $\mathrm{pH} 7.0$ to $\mathrm{pH} 7.4$ to $\mathrm{pH} 8.0$ (data not shown). Since all compounds tested in this study are amines, they would be protonated at acidic $\mathrm{pH}$ and deprotonated at basic $\mathrm{pH}$. Thus, a more potent effect at alkaline $\mathrm{pH}$ could be due to increased affinity of the receptor for the test compound or to unmasking of cryptic receptor sites. Acidic $\mathrm{pH}$ would be expected to have the opposite effect by decreasing the binding of sigma ligands. In this regard, it is interesting to note that the activity of DTG was not as dramatically changed by raising the $\mathrm{pH}$ as compared to the other ligands (Tables 6,7 ). This may be due to the fact that the protonation state of the guanidine, being a strongly basic group, is not changed over this $\mathrm{pH}$ range.

Alternatively, the $\mathrm{pH}$ effect could be due to enhanced access of compounds to the site of action as a result of deprotonation. Sigma receptors have been localized in high density to subcellular fractions of brain tissue, particularly endoplasmic reticular (McCann et al., 1989; McCann and Su, 1990) and mitochondrial fractions (Itzhak et al., 1991), and in lower density in plasma membrane fractions (McCann and $\mathrm{Su}, 1990$ ). Unlike brain tissue, sigma sites of C6 glioma, NIE-115 neuroblastoma, and NG108-15 neuroblastoma-glioma hybrid were found to be concentrated primarily in the crude plasma membrane/mitochondrial $\left(P_{2}\right)$ fraction and not in the microsomal $\left(P_{3}\right)$ fraction, demonstrating that sigma sites are not preferentially localized in the endoplasmic reticulum in all cells (Vilner and Bowen, 1992).
Nonetheless, the localization of sigma binding sites in subcellular fractions could suggest an intracellular site of action for these sigma ligands to produce the morphological and cytotoxic effects. The less polar, deprotonated ligand would be expected to cross the plasma membrane more readily, while the charged protonated ligand would have greater difficulty entering the cells. However, under normal $\mathrm{pH}$ conditions ( $\mathrm{pH} 7.2-7.4)$, there was little correlation of cytotoxic potency with hydrophobicity of the compound, since the polar arylethylene diamines were in some cases more potent than the more hydrophobic neuroleptics. Thus, it appears that a requirement for the compounds to enter cells alone does not totally explain the effect of $\mathrm{pH}$ on activity.

A cytoprotective effect of extracellular acidity has been demonstrated in other cascs. Low $\mathrm{pH}$ has been shown to protect muscle, liver, kidney, and neuronal cells from damage during anoxia, hypoxia, or glucose deprivation (Bing et al., 1973; Pentilla et al., 1976; Burnier et al., 1988; Tombaugh et al., 1990). Furthermore, $\mathrm{pH}$ has been shown to modulate the cellular effects of glutamate agonists in primary cultures of hippocampal or cortical cells: (1) low $\mathrm{pH}$ inhibited and high $\mathrm{pH}$ enhanced the excitatory effects of $10 \mu \mathrm{M}$ NMDA as measured by patch-clamp recording (Giffard et al., 1990; Vyklicky et al., 1990), and (2) low $\mathrm{pH}$ markedly reduced the neurotoxic effects of NMDA receptor agonists and enhanced the neuroprotective effects of MK801 (Giffard et al., 1990; Kaku et al., 1993). It is noteworthy that the morphological effects of sigma ligands on C6 glioma cells and various other cell lines (including cells of neuronal origin) are reminiscent of the effect of NMDA agonists on neuronal cells (Choi et al., 1987), despite the fact that glutamate and NMD $\Lambda$ had no effect on cell lines. This latter point demonstrates that the effect of sigma ligands cannot be due to any mode of activation of the NMDA/PCP receptor complex. However, since low $\mathrm{pH}$ protects cells from the damage produced by both sigma ligands and glutamate, these two agents may have a common mechanism of action at the postreceptor level. It is well established that a rise in intracellular calcium concentration plays a central role in cellular toxicity produced by ischemia, hypoglycemia, and NMDA receptor activation (Rothman and Olney, 1987; Choi, 1988). Furthermore, low pH has been shown to prevent the movement of calcium from external or internal sources into the cytoplasm of heart, liver, and skeletal muscle cells (Nakamaru and Schwartz, 1972; Kim and Smith, 1987; Burnier et al., 1988) and to prevent glutamate-stimulated calcium entry into cortical neurons (Giffard et al., 1990). Therefore, inhibition of calcium fluxes appears to explain the cytoprotective effect of low $\mathrm{pH}$ during hypoxia and glutamate exposure. It is conceivable then that the sigma receptor-mediated changes in cellular morphology and viability as demonstrated here might also involve $\mathrm{pH}$-sensitive modulation of calcium homeostasis. The possible role of $\mathrm{Ca}^{2+}$ in the morphological and cytotoxic effects of sigma ligands will be the object of future study.

Another possible mechanism to consider is one involving binding of the drugs to calmodulin rather than to sigma sites. At high concentrations, antipsychotic drugs from a variety of structural classes have been shown to bind to calmodulin in a calcium-dependent manner, thereby inhibiting the activity of calmodulin-dependent enzymes (Levin and Weiss, 1977, 1979). Phenothiazine-type neuroleptics in particular exhibit this property. However, this mechanism is unlikely to account for the activity of the compounds as demonstrated in the present study. Whereas binding of antipsychotic drugs to calmodulin correlates 
strongly with ability to inhibit the activity of calmodulin-dependent cyclic nucleotide phosphodiesterase, the rank order of potency for these same compounds at producing morphologic and toxic effects in C6 glioma cells did not correlate with calmodulin binding affinity. A comparison of the data in Table 1 with that of Levin and Weiss $(1977,1979)$ regarding calmodulin binding and phosphodiesterase inhibitory activity reveals several discrepancies. Pimozide binds to calmodulin with an affinity 10 -fold higher than haloperidol and is ninefold more potent at inhibiting phosphodiesterase activity; yet haloperidol was much more potent than pimozide at both sigma binding and production of morphologic effects. (+)-Butaclamol exhibited fivefold higher binding affinity for calmodulin compared to (-)-butaclamol, yet while (-)-butaclamol was quite active at producing morphological effects, the (+)-enantiomer was inactive and exhibited 30 -fold lower sigma binding affinity. Similarly, clozapine was nearly 20 times more potent than (-)-butaclamol at hinding to calmodulin, yet was inactive at sigma binding and failed to produce morphological effects at $100 \mu \mathrm{M}$. Finally, the binding of trifluoperazine to calmodulin was found to be inhibited at alkaline $\mathrm{pH}$, whereas both sigma receptor binding and the ability of sigma ligands to produce changes in cell morphology were enhanced at alkaline $\mathrm{pH}$ (Tables 6 and 7). Thus, the morphologic and cytotoxic activity of sigma ligands is not consistent with binding to calmodulin but is consistent with binding to sigma receptors.

It is interesting to note, however, that the phenothiazine-type neuroleptics (fluphenazine, perphenazine, and trifluoperazine) appeared to produce some effects that were distinguishable from those of the other classes of neuroleptics or ethylene diaminetype sigma ligands. Tables 9 and 10 show that, unlike the 300 $\mu \mathrm{M}$ dose of other sigma compounds tested, $300 \mu \mathrm{M}$ of the phenothiazine-related neuroleptics killed a portion of the cells within only 1-3 hr of exposure under normal conditions. Also, Tables 6 and 9 show that while the effects of $30 \mu \mathrm{M}$ and $100 \mu \mathrm{M}$ fluphenazine were attenuated by low $\mathrm{pH}$, the effects of the 300 $\mu \mathrm{M}$ dose were not. Finally, the majority of sigma ligands produced a reversible morphological effect at $b o t h$ the $100 \mu \mathrm{M}$ and $300 \mu \mathrm{M}$ concentration. However, Table 10 shows that while cells preexposed to $100 \mu \mathrm{M}$ fluphenazine, trifluoperazine, or perphenazine recovered completely, cells exposed to the $300 \mu \mathrm{M}$ concentration did not recover from the pretreatment. Thus, whereas the lower doses ( 30 and $100 \mu \mathrm{M}$ ) of phenothiazine neuroleptics produced effects on cells that were similar to the other sigma compounds, the higher dose $(300 \mu \mathrm{M})$ effects appeared to be different. This suggests that effects produced by the $300 \mu \mathrm{M}$ dose of phenothiazines may be mediated by interaction with components other than sigma receptors.

Since the initial effect of sigma ligands was a change in cell shape (the earliest observable effect was withdrawal of processes), one might suspect some effect on cytoskeletal elements. Preliminary studies have shown that $100 \mu \mathrm{M}$ haloperidol, reduced haloperidol, fluphenazine, BD737, LR172, BD1008, DTG, and (+)-pentazocine had no direct effect on the assembly or disassembly of purified microtubule proteins in vitro (K. Boekelheide, personal communication). However, in the living cell, direct effects on microtubles (or other cytoskeletal components that are more closely involved in the maintenance of cell shape) cannot be ruled out at this time. It is obvious that dramatic changes in cytoskeletal proteins must occur to produce such rapid changes in the morphology of these cells. Whether this is a primary effect of sigma ligands or the result of some receptor- mediated cellular signaling pathway will be a point of further investigation.

The effects of sigma compounds were not limited to C6 glioma cells. Sigma ligands caused morphological changes in other cell lines of neuronal and non-neuronal origin. We had shown previously that SK-N-SH, NG108-15, SH-SY5Y, NCB-20, PC12, and COS-7 cells have sigma-1-like binding sites for $\left[{ }^{3} \mathrm{H}\right](+)$ pentazocine, as well as sigma- 2 sites labeled by ${ }^{3} \mathrm{H}-\mathrm{DTG}$ (Hellewell and Bowen, 1990; Vilner and Bowen, 1991, 1992; Vilner et al., 1992 and unpublished observations). Others have also characterized sigma-like binding sites on NCB-20 cells (Kushner et al., 1988; Wu et al., 1991), PC12 cells (Yang et al., 1989), and NG108-15 cells (Georg and Friedl, 1991). We show here that all of these cell lines are sensitive to sigma ligands. A comparison of the effects of sigma ligands across cell lines reveals similar effects, although some cell types appeared more sensitive than others. Also, the MRS-5 lung cell is irradiated to prevent division, and PC12 cells had been differentiated with nerve growth factor prior to testing. The observation that sigma ligands were still effective in these two nondividing cells suggests that stage in the cell cycle plays no particular role.

The apparent cytotoxic effect of sigma ligands on a wide variety of tumor-derived cell lines has important implications. A variety of solid human tumors from various body sites have been shown to express sigma receptors labeled by [ $\left.{ }^{3} \mathrm{H}\right] \mathrm{DTG}$ (Thomas et al., 1990; Bem et al., 1991). The levels of sigma sites expressed in the tumor were significantly higher than that expressed in the normal surrounding tissue. We have now identified sigma sites in several human tumor cell lines (John et al., 1993, 1994a,b; Moody et al., 1994), and it has been demonstrated that sigma sites may be viable as targets for the design of noninvasive tumor imaging agents (John et al., 1993). Taken with the findings of the present study, these observations suggest a role of sigma sites in tumor biology and point to a potential use of sigma ligands as antitumor and/or tumor diagnostic agents.

Since antipsychotic drugs are among the sigma compounds that produce these morphologic and cytotoxic effects, perhaps the most important question concerns the implications for neuroleptic treatment. Neuroleptic drug treatment in humans can cause several motor dysfunctions, some of which are persistent or irreversible (Ayd, 1961; Druckman et al., 1962; Crane et al., 1971; Kennedy et al., 1971; Burke et al., 1982). These include tardive dyskinesia and acute and late-onset dystonias. Sigma receptors occur in high density in motor areas of the brain, particularly the cerebellum, red nucleus, substantia nigra, and brainstem cranial nerve nuclei such as facial, hypoglossal, trigeminal, and oculomotor (Gundlach et al., 1986; McLean and Weber, 1988; Graybiel et al., 1989; Walker et al., 1992). Microinjection of sigma ligands into the rat red nucleus produces alterations in posture that resemble torsion dystonia, whereas microinjection into the substantia nigra produces contralateral circling (Walker et al., 1988, 1993a,b; Goldstein et al., 1989; Matsumoto et al., 1990). These acute motor effects were shortlived and occurred without any obvious histological damage. Thus, sigma receptors may play a role in normal motor function as well as in motor side effects of neuroleptics.

However, two sigma ligands, reduced haloperidol (Bowen et al., 1990) and BD614 (Bowen et al., 1992), when microinjected into the rat red nucleus caused long-lasting postural alterations that appeared to be the result of extensive histopathology in and around the injection site. Furthermore, lesions of the red nucleus have been associated with dystonia in monkeys (Carpenter, 
1956). It is therefore conceivable, in view of the present study, that long-term exposure of neurons or glia to even low doses of neuroleptics or their metabolites might cause gradual, sigma receptor-mediated cellular damage or loss. If this occurs in any of the sigma receptor-rich motor nuclei mentioned above, delayed irreversible motor abnormalities such as tardive dyskinesia could result. Several observations may lend some support to this notion. (1) Reduced haloperidol has been found to accumulate in relatively high amounts in brain tissue of haloperidol-treated patients (Korpi et al., 1984). (2) Subtle morphological changes described as "inflated neurons" have been observed in the cerebellar dentate nucleus of patients suffering from neuroleptic-induced tardive dyskinesia (Arai et al., 1987). (3) The atypical neuroleptics sulpiride and clozapine are reported to have reduced propensity to cause motor anomalies in humans (Matz et al., 1974; Gerlach and Casey, 1984); they both lack affinity for sigma receptors, fail to produce acute dystonic reactions upon rubral microinjection in rats (Walker et al., 1988, 1990; Matsumoto et al., 1990), and fail to produce morphological changes in C6 glioma cells (Table 1). Thus, further studies of the possible role of sigma-induced cellular damage as a contributing factor in tardive dyskinesia and in degenerative motor disorders is warranted, since it may be possible to develop blockers of sigma sites that could attenuate these effects.

Finally, the results of the present study would appear to be at odds with several reports that have described neuroprotective properties of sigma ligands. However, this may not necessarily be the case. These reports describe neuroprotection by sigma ligands in various in vivo models of neurodegeneration (Long et al., 1990; Contreras et al., 1991; Pontecorvo et al., 1991). In those studics, sigma compounds were administered in vivo and are likely to be present at the site of action in much lower concentrations than those used here. There are examples of compounds, for example, $\beta$-amyloid peptide (Yankner et al., 1990), that are neurotrophic at low doses but that become neurotoxic at high doses. Indeed, glutamate itself can be said to have a beneficial function in low concentrations but toxic effects at high or chronic doses. Thus, it is conceivable that sigma compounds might be protective at low doses, and become toxic only in high doses or upon chronic exposure. Furthermore, the ability to subdivide sigma ligands into classes with high, medium, and low efficacy with respect to production of morphological and cytotoxic effects suggests the possibility of agonistantagonist relationships at the sigma site mediating these effects. It is possible, therefore, that agonists at this sigma site could be neurotoxic while antagonists could be neuroprotective, or vice versa. It is important to note here that the mode of in vivo neuroprotection by sigma ligands is not completely understood, since it has not been possible to correlate unequivocally the protection from glutamate neurotoxicity in in vitro models with binding affinity at sigma receptors (DeCoster et al., 1993; Lesage et al., 1993; Lysko, 1993). Thus, sigma compounds that are neuroprotective in vivo could be acting by a mechanism not involving interaction with sigma receptors. Alternatively, in vivo sigma receptors could be involved in protection against cellular injuries other than those directly caused by glutamate. More work will be needed to determine the relationship of the neuroprotective and cytotoxic properties of sigma ligands.

Because the present study is merely descriptive in nature, it is obvious that more work will need to be done to characterize this effect fully. Also, the effect of lower doses of ligand over longer periods of time needs to be investigated. Though the mechanism is not clear at the present time, the data presented here strongly support the involvement of sigma receptors. Thus, sigma sites appear to be involved in some important aspect of cell function such that activation (or inhibition) of these sites produces profound changes in the cells. Implications for cell growth and development are possible, as well as for neurodegeneration and neuroprotection. This opens a new area of investigation regarding elucidation of the functional role and clinical potential of sigma receptors.

\section{References}

Arai N, Amano N, Iseki E, Yokoi S, Saito A, Takekawa Y, Misugi K. (1987) Tardive dyskinesia with inflated neurons of the cerebellar dentate nucleus. Acta Neuropathol (Berl) 73:38-42.

Ayd FJ (1961) A survey of drug-induced extrapyramidal reactions. J Am Med Assoc 175:1054-1060.

Bem WT, Thomas GE, Mamone IY, Homan SM, Levy BK, Johnson FE, Coscia CJ (1991) Overexpression of sigma receptors in nonneural human tumors. Cancer Res 51:6558-6562.

Bing OHL, Brooks WW, Messer JV (1973) Heart muscle viability following hypoxia: protective effect of acidosis. Science 180:12971298.

Bowen WD (1993) Biochemical pharmacology of sigma receptors. In: Aspects of synaptic transmission, Vol II, Acetylcholine, sigma receptors, CCK and eicosanoids, neurotoxins (Stone TW, ed), pp 113-136. London: Taylor and Francis.

Bowen WD, Hellewell SB, McGarry KA (1989) Evidence for a multisite model of the rat brain sigma receptor. Eur J Pharmacol 163:309318.

Bowen WD, Moses EL, Tolentino PJ, Walker JM (1990) Metabolites of haloperidol display preferential activity at sigma receptors compared to dopamine D-2 receptors. Eur J Pharmacol 177:111-118.

Bowen WD, Walker JM, de Costa BR, Wu R, Tolentino PJ, Finn D, Rothman RB, Rice KC (1992) Characterization of the enantiomers of $c i s-N-[2-(3,4-$ dichlorophenyl)ethyl]- $N$-methyl-2-(1-pyrrolidinyl)cyclohexylamine (BD737 and BD738): novel compounds with high affinity, selectivity, and biological efficacy at sigma receptors. J Pharmacol Exp Ther 262:32-40.

Bowen WD, de Costa BR, Hellewell SB, Walker JM, Rice KC (1993) $\left[{ }^{3} \mathrm{H}\right](+)$-Pentazocine: a potent and highly selective benzomorphanbased probe for sigma-1 receptors. Mol Neuropharmacol 3:117-126.

Burke RE, Fahn S, Jankovic J, Marsden CD, Lang AE, Gollomp S, Ilson J (1982) Tardive dystonia: late-onset and persistent dystonia caused by antipsychotic drugs. Neurology 32:1335-1346.

Burnier M, Van Putten VI, Schieppati A, Schrier RW (1988) Effect of extracellular acidosis on ${ }^{45} \mathrm{Ca}^{++}$uptake in isolated hypoxic proximal tubules. Am J Physiol 254:C839-C846.

Carpenter MB (1956) A study of the red nucleus in the rhesus monkey: anatomical degeneration and physiologic effects resulting from localized lesions of the red nucleus. J Comp Neurol 105:195-249.

Carroll FI, Abraham P, Parham K, Bai X, Zhang X, Brine GA, Mascarella SW, Martin BR, May EL, Sauss C, Di Paolo L, Wallace P, Walker JM, Bowen WD (1992a) Enantiomeric $N$-substituted $N$-normetazocines: a comparative study of affinities at sigma, PCP, and mu opioid receptors. J Med Chem 35:2812-2818.

Carroll FI, Bai X, Zhang X, Brine GA, Mascarella SW, Di Paolo L, Wallace P, Walker JM, Bowen WD (1992b) Synthesis, binding (sigma site) and pharmacophore model of $N$-substituted $N$-normetazocine and $N$-nordeoxymetazocine analogs. Med Chem Res 2:3-9.

Cheng Y-C, Prusoff WH (1973) Relationship between the inhibition constant $\left(K_{i}\right)$ and the concentration of inhibitor which causes 50 percent inhibition $\left(\mathbf{I}_{30}\right)$ of an enzymatic reaction. Biochem Pharmacol 22:3099-3108.

Choi DW (1988) Calcium-mediated neurotoxicity: relationship to specific channel types and role in ischemic damage. Trends Neurosci 11: $465-469$.

Choi DW, Maulucci-Gedde M, Kriegstein AR (1987) Glutamate neurotoxicity in cortical cell culture. J Neurosci 7:357-368.

Contreras PC, Ragan DM, Bremer ME, Lanthorn TH, Gray NM, Iyengar S, Jacobson AE, Rice KC, de Costa BR (1991) Evaluation of $\mathrm{U}-50,488 \mathrm{H}$ analogs for neuroprotective activity in the gerbil. Brain Res 546:79-82. 
Crane GE, Naranjo ER (1971) Motor disorders induced by neuroleptics: a proposed new classification. Arch Gen Psychiatry 24:179-184.

Debonnel $G$ (1993) Current hypotheses on sigma receptors and their physiological role: possible implications in psychiatry. J Psychiatry Neurosci 18:157-172.

de Costa BR, Bowen WD, Hellewell SB, Walker JM, Thurkauf A, Jacobson AE, Rice KC (1989) Synthesis and evaluation of optically pure $\left[{ }^{3} \mathrm{H}\right](+)$-pentazocine, a highly potent and selective radioligand for sigma receptors. FEBS Lett 251:53-58.

de Costa BR, Radesca L, Di Paolo L, Bowen WD (1992a) Synthesis, characterization and biological evaluation of a novel class of $N$-(arylethyl)- $N$-alkyl-2-(1-pyrrolidinyl)ethylamines: structural requirements and binding affinity at the sigma receptor. J Med Chem $35: 38-47$.

de Costa BR, Dominguez C, He X-S, Williams W, Radesca L, Bowen W (1992b) Synthesis and biological evaluation of conformationally restricted 2-(1-pyrrolidinyl)- $N$-[2-(3,4-dichlorophenyl)ethyl]- $N$-methyl ethylenediamines as sigma receptor ligands. 1. Pyrrolidine, piperidine, homopiperidine and tetrahydroisoquinoline classes. J Med Chem 35:4334-4343.

dc Costa BR, Hc X-S, Linders JTM, Dominguez C, Gu ZQ, Williams W, Bowen WD (1993) Synthesis and evaluation of conformationally restricted $N$-[2-(3,4-dichlorophenyl)ethyl]- $N$-methyl-2-(1-pyrrolidinyl)ethylamines at sigma receptors. 2. Piperazines, bicyclic amines, bridged bicyclic amines and miscellaneous compounds. J Med Chem 36:2311-2320.

DeCoster M, Knight E, Tortella F (1993) Role of sigma receptors in dextromethorphan mediated neuroprotection. Soc Neurosci Abstr 19: 1348.

DeHaven-Hudkins DL, Ford-Rice FY, Allen JT, Hudkins RL (1993) Allosteric modulation of ligand binding to $\left[{ }^{3} \mathrm{H}\right](+)$-pentazocine-defined sigma recognition sites by phenytoin. Life Sci 53:41-48.

Di Paolo L, Carroll FI, Abraham P, Bai X, Parham K, Mascarella SW, Zhang X, Wallace P, Walker JM, Bowen WD (1991) $N$-substituted derivatives of normetazocinc: differentiation of sigma-1 and sigma-2 receptors. Soc Neurosci Abstr 17:814.

Druckman R, Seelinger D, Thulin B (1962) Chronic involuntary movements induced by phenothiazines. J Nerv Ment Disord 135:6976.

Ferris CD, Hirsh DJ, Brooks BP, Snyder SH (1991) Sigma receptors: from molecule to man. J Neurochem 57:729-737.

Georg A, Friedl A (1991) Identification and characterization of two sigma-like binding sites in the mouse neuroblastoma $\times$ rat glioma hybrid cell line NG108-15. J Pharmacol Exp Ther 259:479-483.

Gerlach J, Casey DE (1984) Sulpiride in tardive dyskinesia. Acta Psychiatr Scand [Suppl] 311:93-102.

Giffard RG, Monyer H, Christine CW, Choi DW (1990) Acidosis reduces NMDA receptor activation, glutamate neurotoxicity, and oxygen-glucose deprivation neuronal injury in cortical ncurons. Brain Res 506:339-342.

Goldstein SR, Matsumoto RR, Thompson TL, Patrick RL, Bowen WD, Walker JM (1989) Motor effects of two sigma ligands mediated by nigrostriatal dopamine neurons. Synapse 4:254-258.

Graybiel AM, Besson M-J, Weber E (1989) Neuroleptic-sensitive binding sites in the nigrostriatal system: evidence for differential distribution of sigma sites in the substantia nigra pars compacta of the cat. J Neurosci 9:326-338.

Gundlach AL, Largent BL, Snyder SH (1986) Autoradiographic localization of sigma receptor binding sites in guinea pig and rat central nervous system with (+)-[3 $\mathrm{H}]-3$-(3-hydroxyphenyl)- $N$-(1-propyl)-piperidine. J Neurosci 6:1757-1770.

He X-S, Bowen WD, Lee KS, Williams W, Weinberger DR, de Costa BR (1993) Synthesis and binding characteristics of potential SPECT imaging agents for sigma- 1 and sigma-2 binding sites. J Med Chem 36:566-572.

Hellewell SB, Bowen WD (1990) A sigma-like binding site in rat pheochromocytoma (PC12) cells: decreased affinity for $(+)$-benzomorphans and lower molecular weight suggest a different sigma receptor form from that in guinea pig brain. Brain Res 527:244-253.

Hellewell SB, Bruce A, Feinstein G, Orringer J, Williams W, Bowen WD (1994) Rat liver and kidney contain high densities of sigma-1 and sigma-2 receptors: characterization by ligand binding and photoaffinity labeling. Eur J Pharmacol [Mol Pharmacol] 268:9-18.

Itzhak Y, Stein I (1990) Sigma binding sites in the brain: an emerging concept for multiple sites and their relevance for psychiatric disorders. Life Sci 47:1073-1081.
Itzhak Y, Stein I, Zhang S-H, Kassim CO, Cristante D (1991) Binding of sigma-ligands to $\mathrm{C} 57 \mathrm{BL} / 6$ mouse brain membranes: effects of monoamine oxidase inhibitors and subcellular distribution studies suggest the existence of sigma-receptor subtypes. J Pharmacol Exp Ther 257:141-148.

John CS, Bowen WD, Saga T, Kinuya S, Vilner BJ, Baumgold J, Paik CH, Reba RC, Neumann RD, Varma VM, McAfee JG (1993) A new malignant melanoma imaging agent: synthesis, characterization, in vitro binding and biodistribution of iodine-125-(2-piperidinylaminoethyl)4-iodobenzamide. J Nucl Med 34:2169-2175.

John CS, Baumgold J, Vilner BJ, McAfee JG, Bowen WD (1994a) [ $\left.{ }^{125} \mathrm{I}\right] N$-(2-piperidinylaminoethyl)4-iodobenzamide and related analogs as sigma receptor imaging agents: high affinity binding to human malignant melanoma and rat $\mathrm{C} 6$ glioma cell lines. J Labelled Comp Radiopharm 33:242-244.

John CS, Vilner BJ, Bowen WD (1994) Synthesis and characterization of [ $\left.{ }^{125} I\right](N$-benzylpiperidin-4-yl)4-iodobenzamide, 4-IBP, a new sigma receptor radiopharmaceutical: high affinity binding to MCF-7 breast tumor cells. J Med Chem 37:1737-1739.

Kaku DA, Giffard RG, Choi DW (1993) Neuroprotective effects of glutamatc antagonists and cxtraccllular acidity. Science 260:15161518.

Kennedy PF, Hershon HI, McGuire RJ (1971) Extrapyramidal disorders after prolonged phenothiazine therapy. $\mathrm{Br} \mathrm{J}$ Psychiatry 118: $509-518$.

Kim D, Smith TW (1987) Altered Ca fluxes and contractile state during $\mathrm{pH}$ changes in cultured heart cells. Am J Physiol 253:C137-C146.

Korpi ER, Kleinman JE, Costakos DT, Lannoila M, Wyatt RJ (1984) Reduced haloperidol in the post-mortem brains of haloperidol-treated patients. Psychiatry Res 11:259-269.

Kushner L, Zukin SR, Zukin RS (1988) Characterization of opioid, sigma, and phencyclidine receptors in the neuroblastoma-brain hybrid cell line NCB-20. Mol Pharmacol 34:689-694.

Largent BL, Wikstrom H, Gundlach AL, Snyder SH (1987) Structural determinants of sigma receptor affinity. Mol Pharmacol 32:772-784.

Lee KS, He X-S, de Costa BR, Bowen WD, Sassaman MB, Rice KC, Weinberger DR (1992) Radioiodination of a novel candidate for SPECT imaging of sigma receptors. Soc Nucl Med 39th Annu Meeting Abstr.

Lesage AS, De Loore K, Leysen JE (1993) Sigma sites 1 and 2 are not involved in neuroprotection governed by sigma ligands in primary hippocampal cultures. Soc Neurosci Abstr 19:1347.

Levin RM, Weiss B (1977) Binding of trifluoperazine to the calciumdependent activator of cyclic nucleotide phosphodiesterase. Mol Pharmacol 13:690-697.

Levin RM, Weiss B (1979) Selective binding of antipsychotics and other psychoactive agents to the calcium-dependent activator of cyclic nucleotide phosphodiesterase. J Pharmacol Exp Ther 208:454-459.

Long JB, Tidwell RE, Tortella FC, Rice KC, de Costa BR (1990) Selective sigma ligands protect against dynorphin A-induced spinal cord injury in rats. Soc Neurosci Abstr 16:1122.

Lowry OH, Rosenbrough NJ, Farr AL, Randall RJ (1951) Protein measurement with the Folin phenol reagent. J Biol Chem 193:265271.

Lysko PG (1993) Excitatory amino acid neurotoxicity at the $N$-methylD-aspartate receptor: protection by sigma agonists. In: Glutamate: transmitter and toxin (Kempski O, ed), pp 86-94. Munich: Zuckschwerdt.

Matsumoto RR, Hemstreet MK, Lai N, Thurkauf A, de Costa BR, Rice KC, Hellewell SB, Bowen WD, Walker JM (1990) Drug specificity of pharmacological dystonia. Pharmacol Biochem Behav 36:151-155.

Matz R, Rick W, Oh D, Thompson H, Gershon S (1974) Clozapine: a potential antipsychotic agent without extrapyramidal manifestations. Curr Ther Res 16:687-695.

McCann DJ, Su T-P (1990) Haloperidol-sensitive (+)-[ $\left.{ }^{3} \mathrm{H}\right]$ SKF-10,047 binding sites (sigma sites) exhibit a unique distribution in rat brain subcellular fractions. Eur J Pharmacol 188:211-218.

McCann DJ, Su T-P (1991) Solubilization and characterization of haloperidol-sensitive ( + )-[ $\left.{ }^{3} \mathrm{H}\right] \mathrm{SKF} 10,047$ binding sites (sigma sites) from rat liver membranes. J Pharmacol Exp Ther 257:547-554.

McCann DJ, Rabin RA, Rens-Domiano S, Winter JC (1989) Phencyclidine/SKF 10,047 binding sites: evaluation of function. Pharmacol Biochem Behav 32:87-94.

McI ean S, Weber E (1988) Autoradiographic visualization of haloperidol-sensitive sigma receptors in guinea pig brain. Neuroscience 25:259-269. 
Moody TW, Bowen WD, Vilner BJ, McAfee JG, John CS (1994) Sigma receptor ligands localize to non-small cell lung tumors. Proc Am Assoc Cancer Res 1587:266.

Musacchio JM, Klein M, Canoll PD (1989a) Dextromethorphan and sigma ligands: common sites but diverse effects. Life Sci 45:17211732.

Musacchio JM, Klcin M, Paturzo JJ (1989b) Effects of dextromethorphan site ligands and allosteric modifiers on the binding of $(+)$ [ $\left.{ }^{3} \mathrm{H}\right] 3-(-3-h y d r o x y p h e n y l)-N-1-($ propyl)piperidine. Mol Pharmacol 35: $1-5$.

Nakamaru Y, Schwartz A (1972) The influence of hydrogen ion concentration on calcium binding and release by skeletal muscle sarcoplasmic reticulum. J Gen Physiol 59:22-32.

Paul IA, Basile AS, Rojas E, Youdim MBH, de Costa B, Skolnick P, Pollard HB, Kuijpers GAJ (1993) Sigma receptors modulate nicotinic receptor function in adrenal chromaffin cells. FASEB J 7:11711178.

Penttila A, Glaumann H, Trump BF (1976) Studies on the modification of the cellular response to injury. IV. Protective effect of extracellular acidosis against anoxia, thermal, and $p$-chloromercuribenzene sulfonic acid treatment of isolated rat liver cells. Life Sci 18: 1419-1430.

Pontecorvo MJ, Karbon EW, Goode S, Clissold DB, Borosky SA, Patch RJ, Ferkany JW (1991) Possible cerebroprotective and in vivo NMDA antagonist activities of sigma agents. Brain Res Bull 26:461-465.

Quirion R, Bowen WD, Itzhak Y, Junien JL, Musacchio JM, Rothman RR, Su T-P, Tam SW, Taylor DP (1992) A proposal for the classification of sigma binding sites. Trends Pharmacol Sci 13:85-86.

Radesca L, Bowen WD, Di Paolo L, de Costa BD (1991) Synthesis and receptor binding of enantiomeric $N$-substituted $c i s-N-[2-(3,4-$ dichlorophenyl)ethyl]-2-(1-pyrrolidinyl)cyclohexylamines as high affinity sigma receptor ligands. J Med Chem 34:3058-3065.

Rothman RB, Reid A, Mahboubi A, Kim C-H, de Costa BR, Jacobson AE, Rice KC (1991) Labeling by $\left[{ }^{3} \mathrm{H}\right] 1$,3-di(2-tolyl)guanidine of two high affinity binding sites in guinea pig brain: evidence for allosteric regulation by calcium channel antagonists and pseudoallosteric modulation by sigma ligands. Mol Pharmacol 39:222-232.

Rothman SM, Olney JW (1987) Excitotoxicity and the NMDA receptor. Trends Neurosci 10:299-302.

Su TP (1991) Sigma receptors: putative links between nervous, endocrine, and immune systems. Eur J Biochem 200:633-642.

Thomas GE, Szucs M, Mamone JY, Bem WT, Rush MD, Johnson FE, Coscia CJ (1990) Sigma and opioid receptors in human brain tumors. Life Sci 46:1279-1286.

Tombaugh GC, Sapolsky RM (1990) Mild acidosis protects hippocampal neurons from injury induced by oxygen and glucose deprivation. Brain Res 506:343-345.

Vilner BJ, Bowen WD (1991) Characterization of $\left[{ }^{3} \mathrm{H}\right] \mathrm{DTG}$ and $\left[{ }^{3} \mathrm{H}\right](+)-$
3-PPP binding sites of NB41A3 neuroblastoma, C6 glioma, and NG108-15 hybrid cells. Soc Neurosci Abstr 17:593.

Vilner BJ, Bowen WD (1992) Characterization of sigma-like binding sites of NB41 A3, S-20Y, and N1E-1 15 neuroblastomas, C6 glioma, and NG108-15 neuroblastoma-glioma hybrid cells: further evidence for sigma-2 receptors. In: Multiple sigma and PCP receptor ligands: mechanisms for neuromodulation and ncuroprotcction? (Kamenka JM, Domino EF, eds), pp 341-353. Ann Arbor, MI: NPP Books.

Vilner BJ, Bowen WD (1993) Sigma receptor-active neuroleptics are cytotoxic to $\mathrm{C} 6$ gliona cells in culture. Eur J Pharmacol [Mol Pharacol] 244:199-201.

Vilner BJ, de Costa BR, Bowen WD (1992) Characterization of a novel sigma-like binding site for $\left[{ }^{3} \mathrm{H}\right](+)$-pentazocine in clonal cell lines. Soc Neurosci Abstr 18:22.

Vyklicky L Jr, Vlachova V, Krusek J (1990) The effect of external pH changes on responses to excitatory amino acids in mouse hippocampal neurones. J Physiol (Lond) 430:497-517.

Walker JM, Matsumoto RR, Bowen WD, Gans DL, Jones KD, Walker FO (1988) Evidence for a role of haloperidol-sensitive sigma "opiate" receptors in the motor effects of antipsychotic drugs. Neurology 38:961-965.

Walker JM, Bowen WD, Walker FO, Matsumoto RR, de Costa BR, Rice KC (1990) Sigma receptors: biology and function. Pharmacol Rev 42:355-402.

Walker JM, Bowen WD, Goldstein SR, Roberts AH, Patrick SL, Hohmann AG, de Costa BR (1992) Autoradiographic distribution of $\left[{ }^{3} \mathrm{H}\right]-(+)$-pentazocine and $\left[{ }^{3} \mathrm{H}\right] 1,3$-di- $O$-tolylguanidine (DTG) binding sites in guinea pig brain: a comparative study. Brain Res 581:33-38.

Walker JM, Bowen WD, Patrick SL, Williams WE, Mascarella SW, Bai $X$, Carroll FI (1993a) A comparison of (-)-deoxybenzomorphans devoid of opiate activity with their dextrorotatory phenolic counterparts suggests role of sigma-2 receptors in motor function. Eur J Pharmacol 231:61-68.

Walker JM, Hohmann AG, Hemstreet MK, Martin WJ, Beierlein M, Roth JS, Patrick SL, Carroll FI, Patrick RL (1993b) Aspects of synaptic transmission, Vol II, Acetylcholine, sigma receptors, CCK and eicosanoids, neurotoxins (Stone TW, ed), p 91-112. London: Taylor and Francis.

Wu X-Z, Bell JA, Spivak CE, London ED, Su T-P (1991) Electrophysiological and binding studies on intact NCB-20 cells suggest presence of low affinity sigma receptor. J Pharmacol Exp Ther 257:351359.

Yang ZW, Paleos GA, Byrd JC (1989) Expression of (+)-3-PPP binding sites in the PC12 pheochromocytoma cell line. Eur J Pharmacol 164:607-610.

Yankner BA, Duffy LK, Kirschner DA (1990) Neurotrophic and neurotoxic effects of amyloid $\beta$ protein: reversal by tachykinin neuropeptides. Science 250:279-282. 